\title{
International Corporate Governance Spillovers: Evidence from Cross-Border Mergers and Acquisitions
}

Rui Albuquerque, Luis Brandao-Marques, Miguel A. Ferreira, Pedro Matos 


\title{
IMF Working Paper
}

Institute for Capacity Development

\section{International Corporate Governance Spillovers: Evidence from Cross-Border Mergers and Acquisitions}

\section{Prepared by Rui Albuquerque, Luis Brandao-Marques, Miguel A. Ferreira, and Pedro Matos*}

Authorized for distribution by Jorge Roldos

November 2013

\section{This Working Paper should not be reported as representing the views of the IMF.} The views expressed in this Working Paper are those of the author(s) and do not necessarily represent those of the IMF or IMF policy. Working Papers describe research in progress by the author(s) and are published to elicit comments and to further debate.

\begin{abstract}
We develop and test the hypothesis that foreign direct investment promotes corporate governance spillovers in the host country. Using firm-level data on cross-border mergers and acquisitions (M\&A) and corporate governance in 22 countries, we find that cross-border M\&As are associated with subsequent improvements in the governance, valuation, and productivity of the target firms' local rivals. This positive spillover effect is stronger when the acquirer is from a country with stronger shareholder protection and if the target's industry is more competitive. We conclude that the international market for corporate control promotes the adoption of better corporate governance practices around the world.

JEL Classification Numbers: G32, G34, G38

Keywords: Foreign direct investment, Corporate governance, Cross border mergers and acquisitions, Spillovers

Author's E-Mail Address: ralbuque@ bu.edu, 1marques@imf.org, miguel.ferreira@novasbe.pt, MatosP@darden.virginia.edu

\footnotetext{
* Albuquerque: Boston University, Católica-Lisbon School of Business and Economics, CEPR, and ECGI. Brandao-Marques: International Monetary Fund. Ferreira: Nova School of Business and Economics, and ECGI. Matos: University of Virginia - Darden School of Business, and ECGI.
} 
I. Introduction

II. The Model 6

III. Data

IV. Corporate Governance Spillovers of Cross-Border Mergers and Acquisitions. 11

A. Corporate Governance Results.......................................................................11

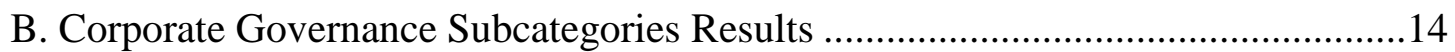

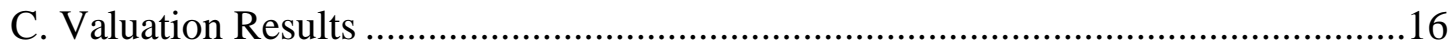

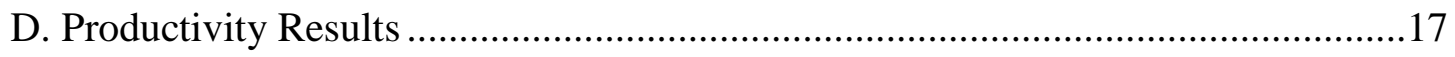

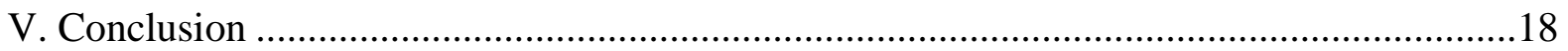

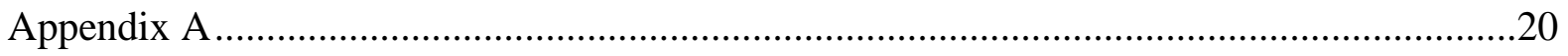

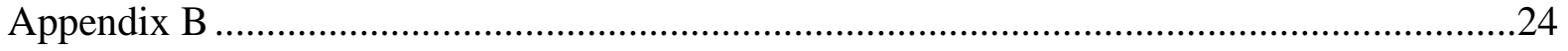

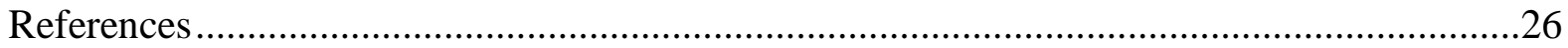

\section{TABLES}

Table 1 - Corporate Governance and Cross-Border M\&A by Target Country ........................28

Table 2 - Corporate Governance and Cross-Border M\&A by Industry ...................................29

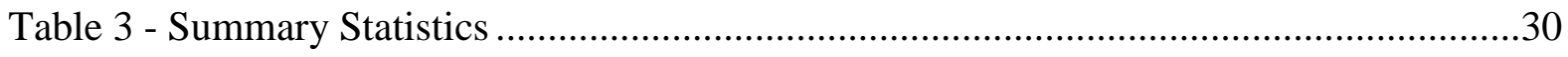

Table 4 - Cross-Border M\&A and Non-Target Corporate Governance: Firm Fixed Effects..31

Table 5 - Cross-Border M\&A and Non-Target Corporate Governance: First Differences ......32

Table 6 - Cross-Border M\&A and Non-Target Corporate Governance: Robustness ...............33

Table 7 - Cross-Border M\&A and Non-Target Corporate Governance Subcategories .............35

Table 8 - Cross-Border M\&A and Non-Target Firm Valuation: Firm Fixed Effects...............37

Table 9 - Cross-Border M\&A and Non-Target Firm Valuation: First Differences ..................38

Table 10 - Cross-Border M\&A and Non-Target Firm Productivity: Firm Fixed Effects.........39

Table 11 - Cross-Border M\&A and Non-Target Firm Productivity: First Differences ............40 


\section{INTRODUCTION}

Foreign direct investment (FDI) has been an increasingly important component of the financial globalization phenomenon in recent decades. According to the World Development Indicators database, the yearly average ratio of the world FDI net inflows to gross domestic product has increased nearly four times from $0.7 \%$ in the 1980 's to $2.6 \%$ in the 2000 's and, consequently, the foreign share of aggregate output has risen dramatically. Cross-border mergers and acquisitions (M\&A) represent more than half of the FDI (Organization for Economic Co-Operation and Development (2007)) with the value of cross-border deals exceeding that of domestic M\&As during the mid-2000s merger boom and also more recently (Economist (2007), Bloomberg (2012)).

FDI can be a source of valuable technology and know-how by promoting linkages with host country firms, which can generate improvements in productivity. However, empirically there is mixed evidence of positive productivity spillovers associated with FDI due to data limitations and multiple effects at play (e.g., Haddad and Harrison (1993), Aitken and Harrison (1999), Javorcik (2004), Haskel, Pereira, Slaughter (2007)). If foreign firms achieve higher productivity at the expense of lower productivity of host country firms there may be adverse effects of FDI on productivity due to competition. Further, FDI spillover effects may be limited due to lack of absorptive capacity in developing countries.

One overlooked aspect is that FDI can be a source of corporate governance improvements in the host country. An active international market for corporate control can substitute for weak investor protection and legal institutions in the host country. Research supports the idea that cross-border M\&As bring corporate governance improvements to target firms. Rossi and Volpin (2004) find that firms based in weak legal environments are frequently targets of acquisitions by firms located in strong legal environments. Bris and Cabolis (2008) and Martynova and Renneboog (2008) find that cross-border corporate transactions generate substantial valuation gains when the acquirer firm's country has stronger investor protection than the target firm's country. ${ }^{1}$ However, these authors do not provide evidence of actual firm-level governance improvements.

In this paper, we investigate whether the change in corporate control following a crossborder M\&A leads to changes in corporate governance of non-target firms that operate in the same country and industry as the target firm. We focus on the strategic complementarity in governance choices between the target firm and its rival firms in the local market. ${ }^{2}$ We take

\footnotetext{
${ }^{1}$ Servaes and Tamayo (2012) show evidence that when a firm is targeted by a hostile takeover attempt its rival firms respond by improving the quality of financial reporting, as well as by cutting capital expenditures and increasing net debt.

${ }^{2}$ It is empirically difficult to measure the effects on target firms as these firms are frequently delisted following the purchase of a majority stake.
} 
the view that corporate governance is affected by the choice of other competing firms as in the models developed by Acharya and Volpin (2010), Cheng (2010), and Dicks (2012).

To provide guidance for our empirical analysis, we develop a simple industry oligopoly model, which captures the idea that rival firms operating in a given industry change their governance in response to competitive forces. The spillover effect occurs as firms in an industry recognize that corporate governance is used more efficiently by the target firm and therefore strengthen their own governance as a response. The model has two decision stages and builds on the work of Shleifer and Wolfenzon (2002) and Albuquerque and Wang (2008). In the first stage, outside shareholders choose firm-level governance (i.e., how much to monitor and limit of managerial private benefits), given the governance choices of other firms. In the second stage, firm managers choose output and the level of private benefits that they extract in the context of a symmetric oligopolistic industry. In the Nash equilibrium outcome, managers have an incentive to "overproduce" (because their private benefits increase with revenues) and industry-level profits are not maximized.

The model allows us to examine the effects of a cross-border M\&A. If a firm is the target of a cross-border $\mathrm{M} \& \mathrm{~A}$ and the acquirer firm imposes a higher level of governance (and therefore its managers enjoy a lower level of private benefits), then other firms in the same industry will need to adjust their equilibrium private benefits and output. We derive the following hypotheses on the spillover effects of cross-border M\&As. First, better governance imposed on the target firm leads to lower private benefits in the targets' local rival firms. Intuitively, when the target improves its governance, and thus reduces overproduction, more rents can be extracted by other firms in the oligopoly. These additional rents increase the marginal benefit to improving governance as otherwise more private benefits are extracted by managers. This provides the first testable hypothesis: following a cross-border M\&A from a high governance acquirer firm, we expect a positive governance spillover as the target's local rival firms have an incentive to improve their governance.

Second, we consider how the spillover effect varies with the intensity of product market competition. The model suggests that when governance improves in a firm, and more rents are available to competitors, it pays off to improve governance especially if governance is low, which is true when the number of firms is large and there is more competition. This provides the second testable hypothesis: following a cross-border M\&A from a high governance acquirer firm, we expect a more pronounced positive spillover to the governance of the target's local rival firms in more competitive industries.

We empirically study these questions using a firm-level sample of cross-border M\&As and corporate governance indices in 22 countries in the 2004-2008 period. Our dependent variable is firm-level governance and our main explanatory variable is the entry of foreign firms into an industry via cross-border M\&As. We measure the mean transaction value of cross-border acquisitions in the target firm's industry (at the two-digit SIC level) as a fraction of the industry's market capitalization in each country and year. Following Aggarwal, Erel, 
Ferreira, and Matos (2011), we measure firm-level governance using the percentage of attributes for which the firms meet the minimum acceptable requirements out of 41 attributes (in terms of board, audit, anti-takeover provisions, and compensation and ownership). The data source is RiskMetrics, the leading proxy advisory firm in the world.

We find that cross-border M\&As lead to significant positive governance spillovers within the target firm's industry. We show that the positive relation between cross-border M\&A and rival firm's corporate governance remains strong after controlling for covariates such as firm size, growth opportunities, leverage, tangibility, ownership structure, among others. Furthermore, the results are unchanged after the inclusion of firm fixed effects, suggesting that time-invariant unobserved firm characteristics cannot explain our findings. We also use an instrumental variables approach to provide evidence that causality runs from cross-border M\&A to governance improvements, rather than in the reverse direction.

The magnitude of the corporate governance spillover is heterogeneous across firms. The effect is more pronounced when the acquirer firm comes from a country with a better legal environment than the one in the target firm's country, which is consistent with the first hypothesis that shareholders of non-target firms have an incentive to improve their governance when the acquirer firm comes from a high governance environment as it is more likely to impose similar standards on the target firm. Furthermore, the corporate governance spillovers are more pronounced when the target firm faces tougher product market competition as competitive forces spur the impact of governance improvements in the target firm's rivals. This is consistent with the second hypothesis.

The magnitude of the spillover effects is economically significant. The improvement in governance in a non-target firm is as high as 5 percentage points in perfectly competitive industries when the acquirer country investor protection is better than that of the target country. This corresponds to twice the annual variation in the governance index $(2.2 \%)$ or to the firm adopting 2 (out of 41) additional governance provisions. Government regulatory reforms (e.g., the Sarbanes-Oxley Act) typically do not affect as many governance mechanisms. In additional tests, we also examine spillover results across governance subcategories. Cross-border M\&A activity in an industry seems to affect internal governance mechanism (board structure and executive compensation) rather than external governance mechanisms (audit and anti-takeover provisions).

Next we test whether the governance spillovers produce real effects. We find that crossborder M\&A activity in an industry is associated with higher valuation of non-target firms. In our sample, a one standard deviation increase in cross-border M\&A activity is associated with a $12 \%$ increase in market-to-book relative to the sample median. This firm-level evidence is consistent with the industry-level evidence in Bris, Brisley, and Cabolis (2008). They find a positive relation between the industry Tobin's $Q$ and the average change in investor protection (difference between acquirer's and target's country investor protection) following a cross-border M\&A. Finally, we find significant productivity spillovers on the 
target firms' rivals following a cross-border M\&A.

Overall, we find that cross-border M\&A in an industry generates positive spillover effects particularly on board structure, compensation and ownership attributes of non-target firms that operate in the same industry as the target firm. These findings suggest that the international market for corporate control spreads corporate governance standards across country borders.

Naturally, there are alternative mechanisms of corporate governance spillovers. For example, Doidge, Karolyi, and Stulz (2004) analyze a firm's decision to cross list in a U.S. exchange as bonding mechanism and Fernandes (2009) documents positive valuation spillover effects to other firms in the local market following the cross listing. Aggarwal, Erel, Ferreira, and Matos (2011) show that cross-border portfolio investment, rather than FDI, is associated with own-firm corporate governance improvements but do not look at externality effects to other firms. However, the potential corporate governance effects are likely to be stronger for FDI than for portfolio investment because foreign direct investors assume control, partially or fully, and are more likely to enact governance changes, which then produce spillover effects in the economy.

\section{THE MODEL}

In this section, we describe a simple model that offers an economic rationale for our main tests. The model is fully developed in Appendix A.

We study an industry with $N$ identical firms, labeled with subscript $i$. In each firm there are managers as well as outside shareholders. ${ }^{3}$ All agents are risk neutral. The model is static with two decision stages. In the first stage, outside shareholders of firm $i$ choose the level of governance, $\phi_{i}$, given the choices of the remaining $N$-1 firms. In the second stage, given the governance choices, managers choose private benefits, $s_{i}$, and production quantity, $q_{i}$, conditional on the choices of other firms. There is a constant marginal cost of $c$ to produce. The demand function is $p=a Q^{-1}$, where $p$ is the price of each unit of output and $Q$ denotes the aggregate supply of the output. In equilibrium, the price is such that the market clears. We solve for the Nash equilibrium in this industry model.

Consider firm $i$ 's manager's second stage problem of choosing private benefits and quantity to maximize her compensation. Her compensation is given by a fixed component,

\footnotetext{
${ }^{3}$ In many countries ownership is significantly concentrated and managers can be broadly interpreted as inside shareholders.
} 
$w_{0}$, an equity component of her share ownership times firm profits, $\alpha \pi_{i}$, and private benefits that may be captured at a cost (Shleifer and Wolfenzon (2002), La Porta, Lopez-de-Silanes, Shleifer, and Vishny (2002)): $s_{i} p q_{i}-\phi_{i} \frac{s_{i}^{2}}{2} p q_{i}$. Private benefits come out of revenues, $p q_{i}$. We model a quadratic cost of extracting private benefits as in Albuquerque and Wang (2008), which depends on the level of governance, $\phi_{i}$, and revenues. Firm $i$ 's profits equal $\pi_{i}=\left(1-s_{i}\right) p q_{i}-c q_{i}$.

In Appendix A, we show that the optimal choice of private benefits is $s_{i}=(1-\alpha) / \phi_{i}$. Private benefits decrease with the manager's equity share and corporate governance. We also show that the optimal quantity choice is such that firms produce more when their governance is weaker. Intuitively, because private benefits are derived from revenues, the manager has incentives to sell more, holding all other firms' quantities constant. Therefore, this behavior generates an externality and "overproduction" in equilibrium. The overproduction story is consistent with evidence of overinvestment in firms with weaker governance (see Harford (1999), Gompers, Ishii, and Metrick (2003), Philippon (2006)).

Consider firm i's outside shareholders's first stage problem. Outside shareholders maximize their share of profits net of CEO wage and net of the cost of improving governance, which we model as $d \eta^{-1} \phi_{i}^{\eta}$, where $d$ is a scale parameter and $\eta$ describes how fast the cost of changing governance increases as governance improves. The choice of governance is a trade-off between the benefit of having less revenue be syphoned and the cost of improving governance. We show that when the cost of adopting stronger governance increases, i.e., $d$ increases, governance decreases and private benefits increase. However, when demand is higher, i.e., $a$ increases, the benefits of improving governance increase and private benefits decrease. These two effects are proportional to each other. Finally, increased ex ante competition in the industry, i.e., higher $N$, decreases the ability to extract private benefits and thus decreases the incentives to improve governance.

To model the effects of a cross border acquisition, we assume that one firm, the target of a cross-border M\&A, sets its governance exogenously at a higher level. Other local firms (the target's industry rivals) are free to choose their governance and we show that in the first stage of the game, governance for the other local firms improves as well. This leads to our first hypothesis.

Hypothesis 1: Following a cross-border $M \& A$ from a high governance acquirer firm, we expect non-target local firms operating in the same industry as the target firm to improve their governance.

The intuition is that better governance of the target firm implies a decrease in its overproduction. Therefore, more rents can be extracted by the other local firms in the industry. These additional rents increase the marginal benefit of improving governance for these firms and overall governance increases in equilibrium. 
We show that this effect depends on the level of competition in the industry. In more competitive industries with lower rents, the incentive to improve governance is low and corporate governance is low to start with. When corporate governance improves in the target firm, the steep increase in the marginal benefit to improving governance that arises from the higher revenues to local firms is not matched by a steep increase in the marginal cost of adjusting governance because the overall governance is low (the cost of adjusting governance is convex). This leads to the second hypothesis.

Hypothesis 2: Following a cross-border M\&A from a high governance acquirer firm, we expect the positive spillover to the governance of non-target local firms operating in the same industry as the target firm to be higher in more competitive industries.

The model also has implications for the valuation and productivity of targets' local rival firms. It is simple to extend the model to consider the effects that a cross-border M\&A, which induces a change in the target firm's governance, has on the productivity of the local rival firms. Suppose that output is a Cobb-Douglas production function in a given variable input, such that $q=A x^{\beta}$, where $A$ is a scale parameter, $x$ are input units used in production, and $\beta<1$ is the input's share in production. ${ }^{4}$ If there is overproduction, then there also is over utilization of the input. Consider next the effects of production on productivity, $\frac{q}{x}=A x^{\beta-1}$. Overproduction implies that productivity is too low $(\beta-1<0)$. The reduction in overproduction that occurs when the target firm improves its governance implies that input productivity increases. This leads to two additional hypotheses.

Hypothesis 3: Following a cross-border M\&A from a high governance acquirer firm, we expect the valuation of target and non-target local firms operating in the same industry as the target firm to increase.

Hypothesis 4: Following a cross-border M\&A from a high governance acquirer firm, we expect the productivity of target and non-target local firms operating in the same industry as the target firm to increase.

Although the model has some hypotheses for target firms, we focus on the hypotheses for non-target firms (spillover effects). Target firms in cross-border M\&As that involve the purchase of a majority stake (percentage sought above 50\%) are frequently delisted. Thus, it is empirically difficult to measure the effects on target firms due to a small sample problem.

This model captures the interplay between industry competition, choice of governance, and private benefits in a simple way and its hypotheses can be evaluated with available data.

\footnotetext{
${ }^{4}$ The model results can be restated in terms of labor or capital input because of the relation between $q$ and $x$. The input can either be labor or capital depending on which one firms can most easily adjust or managers prefer to use for empire building.
} 
As more data becomes available, it will be interesting to develop richer models (e.g., endogeneizing the choice of compensation as in Dicks (2012)) that can further extend the understanding of the mechanisms of governance spillovers.

\section{DATA}

Our sample comprises firm-level corporate governance and mergers and acquisitions (M\&As) data. Data on firm-level governance for the period 2004-2008 come from Aggarwal, Erel, Ferreira, and Matos (2011). Governance is measured by an index of 41 attributes (GOV41) divided into four subcategories: board, audit, anti-takeover provisions, and compensation and ownership. The index measures the percentage of attributes in which the firm meets minimum acceptable requirements (an index of $100 \%$ means the firm has adopted all 41 governance provisions). The data come from RiskMetrics, the leading proxy advisory firm in the world.

Data on cross-border M\&As in the 2001-2008 period come from the SDC Platinum database. ${ }^{5}$ We select all completed deals with targets (public and private) originating from countries for which firm-level governance data are available. We exclude leveraged buyouts, spinoffs, recapitalizations, self-tenders, exchange offers, repurchases, minority stake purchases, acquisitions of remaining interest, and privatizations. Of the resulting deals, we keep only those deals with a transaction value of at least one million U.S. dollars. This gives 29,748 M\&A deals, of which 9,710 are cross-border with acquirers coming from 99 countries. We then measure our cross-border M\&A activity (XVAL) as the annual value of cross-border deals as a fraction of market capitalization in the target's country-industry (at the two-digit SIC level). ${ }^{6}$

Although U.S. firms can be acquirers, we focus on non-U.S. target firms and corresponding spillover effects for their local rivals (non-target firms). ${ }^{7}$ The sample covers

\footnotetext{
${ }^{5}$ To focus purely on spillover effects, we exclude firms that were targets in cross-border M\&As in the current year and past three years. These firms would have improved governance because they were a target themselves, rather than due to governance spillovers.

${ }^{6}$ We use a relatively coarse level of aggregation to minimize measurement error. Worldscope assigns to each firm a four-digit code based on the latest available figures of sales. This means that from year to year each firm's industry may vary, especially for large firms, such as the ones we have in our sample. We avoid this problem by aggregating industries to the two-digit level.

${ }^{7}$ We focus on non-U.S. firms for three reasons: (1) corporate governance is typically higher for U.S. firms than for otherwise similar non-U.S. firms (Aggarwal, Erel, Stulz, and Williamson (2009)); (2) results are not affected by the fact that the number of U.S. firms is much larger than that of any other country; and (3) most international corporate governance studies focus on non-U.S. firms (e.g., Doidge, Karolyi, and Stulz, 2004). In robustness tests, we show that results are consistent when we include U.S. target firms in the sample.
} 
2,231 (target and non-target) firms from 22 developed countries during the 2004-2008 period. These are mostly large firms representing about $71 \%$ of the market capitalization of these countries.

Table 1 shows that, on average, the countries with the highest GOV41 are Canada $(67.0 \%)$, the United Kingdom (53.2\%), and Switzerland (50.4\%). The countries with the lowest GOV41 are Greece (33.7\%), Portugal (35.2\%), and Belgium (35.5\%). Average crossborder M\&A activity (XVAL) is the highest in the United Kingdom (with 15.0\%), Norway (with 12.0\%) and the Netherlands (with 7.1\%) and the lowest in Finland and Japan with nearly zero. Table 2 reports the top and bottom ten industries in terms of $X V A L{ }^{8}$ There is considerable variation of cross-border M\&A activity across industries.

We obtain firm characteristics from Worldscope. Table 3 provides summary statistics for the firm-specific control variables used in the regressions. Firm-level controls that are defined as ratios are winsorized at the upper and lower 1\% levels. See Table B1 in Appendix B for detailed variable definitions.

To test the hypotheses on the cross-border spillover effects, we measure country and industry conditions. First, we use the World Economic Forum's country-level index of protections to minority shareholders to build a measure of investor protection to test Hypothesis 1. ${ }^{9}$ We calculate for each cross-border M\&A the difference between the acquirer's and the target's country index. We then create a dummy variable $(I P)$, which takes the value of one when the average (value-weighted using transaction value as weights) across cross-border M\&A deals of this difference in each country-industry is positive, and zero otherwise. Second, we measure product market competition using the Herfindahl-Hirschman index $(H H I)$ based on sales for each country and industry to test Hypothesis 2. A low HHI indicates low concentration in an industry and potentially a more contestable and competitive industry.

\footnotetext{
${ }^{8}$ The $X V A L$ calculation uses the market capitalization of public companies that operate in the same industry as the target firm. Therefore, $X V A L$ can be above $100 \%$ in industries with a significant number of private companies.

${ }^{9}$ The World Economic Forum (WEF) publishes yearly in the Global Competitiveness Report a measure of protection of minority shareholders' interests. This measure is based on a survey of some 14,000 business executives from up to 150 countries. Executives are asked to what extent the interests of minority shareholders are protected by the legal system in their country. Answers range from 1 (not protected at all) to 7 (fully protected). Compared to the measure of investor protection of La Porta, Lopez-de-Silanes, Shleifer, and Vishny (1998) or Djankov, La Porta, Lopez-de-Silanez, and Shleifer (2008) the WEF measure has the advantage of being time-varying and covering almost all the countries in our M\&A sample.
} 


\section{Corporate Governance Spillovers of Cross-Border Mergers AND ACQUISITIONS}

In this section, we study the spillover effects of cross-border M\&As in terms of firm-level corporate governance, market valuation, and productivity of non-target firms operating in the same industry as the target firm.

\section{A. Corporate Governance Results}

We examine the relation between a non-target firm's governance index and the intensity of cross-border M\&A activity in that firm's country-industry. We run the following baseline regression using a firm-year panel:

$$
G O V 41_{i t}=\mu_{i}+\lambda_{t}+\gamma X V A L_{i t-1}+\Gamma Z_{i t-1}+\delta D M A_{i t-1}+u_{i t}
$$

where $G O V 41_{i t}$ is the corporate governance index for firm $i$ in year $t$ and $X V A L_{i t-1}$ is the value of cross-border M\&As in firm $i$ 's country-industry as a fraction of the market capitalization in year $t$-1. The regression equation (1) also includes a firm-level fixed effect $(\mu)$, a year fixed-effect $(\lambda)$, a set of firm-level controls $(Z)$, and a dummy which takes the value of one if there is a domestic M\&A in a firm's industry (DMA). All explanatory variables are lagged by one year. Standard errors are corrected for country-level clustering.

Table 4 reports the firm fixed-effects regression estimates. Column (1) presents estimates without including $X V A L$ and show that the control variables have the expected signs. Corporate governance is positively associated with institutional ownership (IO_TOTAL) but negatively related to the percentage of closely held shares (CLOSE). These estimates are consistent with institutional portfolio investors leading to corporate governance improvements internationally (Aggarwal, Erel, Ferreira, and Matos (2011)).

Our main working hypothesis is that increased cross-border M\&A activity should have a positive spillover effect on the governance of non-target firms operating in the same industry as the target firm. In terms of regression equation (1), we expect to find that the $X V A L$ coefficient is positive and significant. Column (2) presents the estimates of regressions including $X V A L$. The estimated $X V A L$ coefficient is 0.0053 , which is statistically significant at the $5 \%$ level. This coefficient implies that a one standard deviation increase in $X V A L$ is associated with an increase in non-target firms' governance index of 0.3 percentage points $(=$ $0.0053 \times 0.581)$, which represents about $14 \%(=0.3 / 2.17)$ of the average annual increase in GOV41. Notice that this estimate is exclusively driven by the within-firm variation in corporate governance and cross-border M\&A as we are using a firm fixed effects estimator. Unobservable (time invariant) firm heterogeneity does not explain the corporate governance 
spillover effect associated with foreign direct investment in a given industry.

We expect the spillover effect of cross-border M\&As to depend on the quality of governance of the acquirer firms. Specifically, Hypothesis 1 posits that the effect should be larger if the acquirer's country has better investor protection environment than the host country. To test this hypothesis, we expand regression equation (1) to include a measure of the difference in investor protection between the acquirer and target country $(I P)$. The regression includes both the $I P$ dummy and the interaction between $I P$ and XVAL. Column (3) shows that the XVAL coefficient is positive and significant at the $10 \%$ level and the $X V A L$ $\mathrm{x} I P$ coefficient is positive and significant at the $5 \%$ level. This indicates that the governance spillover effect appears to be concentrated in those cross-border deals in which the acquirer country has better investor protection than the target country. Moreover, the interaction term coefficient is more than twice larger than the XVAL coefficient in column (2).

Hypothesis 2 predicts that the corporate governance spillover effect of cross-border M\&As depends on the degree of product market competition in the target firm's industry. To test this hypothesis, we expand regression equation (1) to include a measure of industry concentration given by the Herfindahl-Hirschman index $(H H I)$ based on sales. The regression includes both the $H H I$ variable and the interaction between $H H I$ and XVAL. Column (4) shows that the $X V A L$ coefficient is positive and significant and the $X V A L \times H H I$ coefficient is negative and significant. The interpretation is that the governance spillover is concentrated in those cross-border deals in which the target firm operates in an industry with low concentration (i.e., high competition). The spillover effect is economically three times larger in perfectly competitive industries $(0.0165$ in column (4)) than the average effect $(0.0053$ in column (2)).

Column (5) presents estimates of a regression that includes both the interactions of the cross-border M\&A activity with the difference in investor protection indicator (XVAL x IP) and with industry concentration $(X V A L \times H H I)$, as well as the triple interaction $(X V A L \times I P \times$ $H H I$ ). The $X V A L$ coefficient is 0.0138 with a p-value of 0.02 , which indicates a significant governance spillover in perfectly competitive industries even when there is no difference in investor protection between acquirer and target country industries (i.e., when $I P$ is zero). The interaction $X V A L$ x IP coefficient is 0.0725 and statistically significant, which suggests that there is a governance spillover in perfectly competitive industries when the acquirer country investor protection is better that the target country investor protection. In this case, a one standard deviation increase in $X V A L$ is associated with a 5 percentage points $(=0.581 \times$ $(0.0138+0.0725))$ improvement in governance of non-target firms that operate in the same industry as the target firm. The governance spillover effect is significantly lower in less competitive industries as indicated by the negative and significant $X V A L \times H H I$ coefficient and the triple interaction coefficient. We conclude that the governance spillover effect is highest when the target operates in a competitive industry and the acquirer comes from a country with stronger investor protections than those in the target country. 
One potential concern with the interpretations so far is that causality could run the opposite way. Namely, cross-border deals can be more frequent (higher XVAL) when foreigners are expecting improvements in governance. To address this, we use an instrumental variable approach where we instrument $X V A L$ using import penetration (IMP), defined as the ratio of annual imports to sales in a given country-industry. IMP captures an exogenous factor driving up foreign bidder interest in a given country-industry, irrespective of any anticipation of governance changes. The first-stage regression estimates (untabulated) support the view of a positive relation between cross-border M\&A activity (as proxied by XVAL) and import penetration (as proxied by IMP). The F-statistic (with a value above ten) indicates the rejection of the hypotheses that instruments can be excluded from the first-stage regressions, which suggests that the instruments are not weak. Column (6) of Table 4 provides the second-stage regression estimates and confirms a positive and significant corporate governance spillover effect following cross-border M\&A activity in a given country-industry. The XVAL coefficient in column (6) implies that a one standard deviation increase in $X V A L$ is associated with an increase in non-target firms' governance index of 0.7 percentage points $(=0.1011 \times 0.071)$, which represents about $33 \%$ of the average annual increase in GOV41.

We perform a variety of robustness checks. First, we estimate the regressions in Table 4 using first-differences of the dependent and independent variables plus country, industry, and year fixed effects. The dependent variable is the change in GOV41 from $t-1$ to $t$ and the main independent variable is the change of $X V A L$ from $t-2$ to $t-1$. Table 5 shows that the results in first-differences are consistent with those obtained using firm fixed effects despite the significant reduction in the number of observations. This reinforces our conclusion that changes in M\&A activity leads to subsequent governance changes and not the other way around..$^{10}$

We also conduct the first-differences regression analysis in the reverse direction, using the change in GOV41 as the explanatory variable and the change in $X V A L$ as the dependent variable. We wish to determine whether cross-border M\&A activity drive improvements in governance, or whether improvements in governance attract foreign bids. ${ }^{11}$ We estimate a regression in which the dependent variable is the change in XVAL from $t$ - 1 to $t$ and the main independent variable is the change of GOV41 from $t-2$ to $t-1$. The regression also includes the same control variables used in Table 5. We find that the coefficient on the change in GOV41 is statistically insignificant, which is inconsistent with the reverse effect.

Second, we estimate the firm fixed effects regressions of Table 4 restricting $X V A L$ to

\footnotetext{
${ }^{10}$ Results are also robust when we estimate a pooled OLS regression.

${ }^{11}$ Contemporaneous improvements in governance of the target firm and its rivals could attract foreign bids in the industry.
} 
include only cross-border M\&As in which the acquirer is seeking to own more than $50 \%$ of shareholder's equity. This allows us to focus on the more significant M\&As where majority control is sought by the bidder. The results in Panel A of Table 6 are similar to those of Table 4.

Third, we check the robustness of results to alternatives to the two-digit SIC industry classification used to calculate $X V A L$ as industry boundaries may not be precisely defined. Panel B of Table 6 presents estimates for the regressions in Table 4 but using the 38 FamaFrench industry classification to calculate $X V A L$. The results are similar to those of Table 4, except for the interaction $X V A L \times I P$, which is no longer significant albeit retaining the correct sign.

Finally, we estimate the firm fixed effects regressions of Table 4 using a sample that includes U.S. target firms in addition to non-U.S. firms. Panel C of Table 6 presents the results. In column (1), the $X V A L$ coefficient is higher than that in Table 4. This indicates that governance spillover effects also happen among U.S. industries following a cross-border M\&A in which a non-U.S. firm acquires a U.S. firm. As before, the effect is significantly stronger when the acquirer firm comes from a country with better investor protection than that of the United States. Surprisingly, we find that the level of product market competition does not affect the magnitude of the governance spillover effect. This may be explained by the fact that industry concentration levels are significantly lower in the United States than elsewhere in the world.

In summary, we find strong evidence that cross-border M\&A activity in an industry generates positive corporate governance spillovers to other firms that operate in the same industry. The spillover is more pronounced when the foreign direct investment originates from a country with strong investor protection and product market competition is more intense in the target firm's industry.

\section{B. Corporate Governance Subcategories Results}

We examine 41 firm-level governance attributes using the GOV41 index. Table B2 in the Appendix shows the list of attributes. The attributes cover four broad subcategories: (i) Board (24 attributes), (ii) Audit (3 attributes), (iii) Anti-takeover provisions (6 attributes), and (iv) Compensation and ownership (8 attributes). In this section, we estimate the corporate governance spillover effects generated by cross-border M\&A separately for each governance subcategory.

Panel A of Table 7 shows results of regressions that use the board subcategory as dependent variable. The variable $X V A L$ is insignificant in column (1). In column (2) the variable $X V A L \times I P$ coefficient is positive and significant, which indicates that cross-border M\&A has a positive spillover effect on the quality of the board of directors of non-target 
firms when the acquirer country investor protection is better than the one of the target country. Column (3) indicates that the product market competition effect is statistically insignificant. Column (4) shows results where we include the XVAL x IP and XVAL x HHI interactions as well as the triple interaction $X V A L \times H H I \times I P$. The magnitude of the spillover effect to board attributes is the strongest when the acquirer country investor protection is better than the one of the target country and in competitive industries. The magnitude of the spillover effects is similar to those in Table 4 for the aggregate variable GOV41. ${ }^{12}$

Panels B and C of Table 7 show results of regressions that use the audit and anti-takeover provisions subcategories as dependent variables, respectively. There is no evidence of statistically significant spillover effects of cross-border M\&A activity in the case of these two subcategories.

Panel D of Table 7 shows results of regressions that use the compensation and ownership subcategory as dependent variable. The XVAL is positive and significant in column (1), consistent with a positive spillover effect. In column (2) the XVAL is positive and significant at the $10 \%$ level, which indicates significant spillovers even when the acquirer country has weaker investor protection that the target country. However, the effect is significantly stronger in the case when the acquirer country has stronger investor protection that the target country, as indicated by the positive and significant interaction XVAL x IP coefficient.

Column (3) indicates that significant spillover effects take place regardless of the intensity of product market competition as shown by the positive and significant $X V A L$ coefficient. Column (4) shows results where we include the XVAL x IP and XVAL x $H H I$ interactions as well as the triple interaction $X V A L \times H H I \times I P$. The magnitude of the spillover effect to compensation and ownership attributes is the strongest in perfectly competitive industries and when the acquirer country investor protection is better that the target country investor protection.

Overall, we find that cross-border M\&A activity in an industry generates positive spillover effects on the board, compensation, and ownership of non-target firms that operate in the same industry as the target firm. The effects are not as important in what respects audit and anti-takeover provisions. Thus, cross-border M\&A activity in an industry seems to mainly affect internal governance mechanism rather than external governance mechanisms. One rationale for these findings is that external governance mechanisms such as antitakeover provisions may not be as important outside of the U.S. for lack of an active market for corporate control.

\footnotetext{
${ }^{12}$ For example, the board subcategory spillover effect in more competitive industries when the acquirer country investor protection is better than the target country investor protection (XVAL x IP coefficient in column (4)), a one standard deviation increase in $X V A L$ is associated with a 5.4 percentage points improvement in governance of non-target firms that operate in the same industry as the target firm.
} 


\section{Valuation Results}

The model predicts that acquisitions by foreign rivals will lead to corporate governance improvements and valuation gains to shareholders of non-target firms that operate in the same industry as the rival firm (Hypothesis 3). In this section, we examine whether crossborder M\&A activity in an industry is associated with valuation increases to target firms' local rivals. We use the market-to-book ratio $(M B)$ as the dependent variable and $X V A L$ as the explanatory variable of interest.

Table 8 presents the estimates of firm fixed-effects regressions of $M B$. Regressions include year fixed effects and standard errors are clustered by country. The regressions are estimated by the generalized method of moments (GMM) using the ArellanoBover/Blundell-Bond estimator with forward orthogonal deviations. ${ }^{13}$ Column (1) shows estimates including only control variables. Column (2) shows estimates including XVAL. The $X V A L$ coefficient is positive and significant, which indicates that cross-border M\&A activity in an industry generates positive valuation spillovers to non-target firms operating in the same industry. The effect is economically important. A one standard deviation increase in $X V A L$ is associated with a $12.5 \%(=0.3951 \times 0.581 / 1.842)$ increase in firm valuation at the median of the data. ${ }^{14}$

Column (3) shows that a positive difference in investor protection between acquirer and target country does not increase the non-target firm valuation spillover effect. The coefficient on $X V A L \times I P$ is negative, which is inconsistent with our theory, but its significance disappears when we add more controls in column (5). Column (4) includes HHI and its interaction with $X V A L$ as additional explanatory variables. The results show that the degree of product market competition in the target firm industry is an important determinant of the magnitude of the valuation (and corporate governance) spillover effects to non-target firms. We find that the XVAL coefficient is positive and significant, while the XVAL $\mathrm{x} H H I$ interaction variable is negative and significant. The interpretation is that the valuation spillover effect is concentrated in competitive industries. In the case of perfectly competitive industries, a one standard deviation increase in $X V A L$ is associated with a $31 \%(=0.581 \times$ 0.9955 / 1.842) increase in firm valuation (at the median of the data).

As a robustness check, we estimate the regressions in Table 8 using first-differences of

\footnotetext{
${ }^{13}$ We cannot use standard fixed effects estimator because for the valuation regressions with fixed effects we have a dynamic panel structure since lagged $M B$ is an explanatory variable. For dynamic panels, the consistency of the fixed effects estimator is only valid for fixed $N$ and, given the short time span of our sample, a GMM estimator is preferable.

${ }^{14}$ We compare to the median because the distribution of $M B$ is not symmetric.
} 
the dependent and independent variables plus country, year, and industry fixed effects. Table 9 shows that the results are consistent with those obtained using firm fixed effects. One difference is that results are stronger in column (5) of Table 9 relative to column (5) of Table 8 regarding the interaction of XVAL with $H H I$.

In short, we find that cross-border M\&A activity in an industry generates substantial positive valuation externalities to other firms that operate in the same industry as the target. Product market competition is an important condition for the existence of valuation spillovers, while differences in investor protections do not seem to be crucial for firm valuation spillover effects. ${ }^{15}$

\section{Productivity Results}

To investigate whether cross-border M\&A activity generates productivity spillovers to non-target firms in the same industry, we estimate regressions of firm-level productivity. The model in Section 2 predicts that firms react to acquisitions in their industry from foreign rivals by reducing their production scale and increasing productivity (Hypothesis 4). The choice of the relevant measure of factor productivity depends on which input can be adjusted over the time horizon we employ in our empirical tests. Additionally, managers can extract rents either by accumulating excess capital or hiring too many workers, so it is a priori unclear which measure of factor productivity (labor or capital) matters. Given that our sample is dominated by countries with relatively rigid labor regulations and practices, we use capital as the factor.

The dependent variable is capital productivity, defined as the logarithm of the ratio of output to capital (PRODK), of non-target firms that operate in the same country-industry as the target firm. For output, we use total sales. For capital input, we use property, plant and equipment $(P P E)$. The main explanatory variable is cross-border activity in a countryindustry as measured by $X V A L$. We control for labor input in the regressions using the logarithm of the number of workers (EMPLOYEES) as well as the same set of control variables used in Table 8 . As before, all explanatory variables are lagged by one year. ${ }^{16}$

Table 10 presents the estimates of firm fixed effects regressions of PRODK. Column (1) presents estimates including only control variables. Column (2) includes $X V A L$ and column (3) includes $I P$ and its interaction with $X V A L$, which have insignificant coefficients in both

15 Although the $X V A L$ average effect is economically and statistically significant, the interaction term coefficients are estimated with less precision in the firm valuation regressions. This could be due to the fact that firm valuation is endogenous and therefore these tests lack power.

${ }^{16}$ See Syverson (2011) for a survey on determinants of productivity. 
cases. ${ }^{17}$ Column (4) includes $H H I$ and its interaction with $X V A L$ as additional explanatory variables. Finally, column (5) includes the triple interaction of $X V A L, I P$, and $H H I$. The estimates in columns (4) and (5) show that the degree of product market competition in the industry is an important determinant of the magnitude of productivity spillover effects to non-target firms. The $X V A L$ coefficient is positive and significant, while the $X V A L \times H H I$ interaction variable is negative and significant. The interpretation is that productivity spillover effects are concentrated in competitive industries. ${ }^{18}$ In fact, for a perfectly competitive industry, a one standard deviation increase in $X V A L$ is associated with a $6.8 \%$ (= $0.581 \times 0.1171)$ increase in productivity. For firms in industries with a median level of product market competition, the corresponding increase in productivity is $3.9 \%$.

As a robustness check, we estimate the regressions in Table 10 using first-differences of the dependent and independent variables plus country, year, and industry fixed effects. The results in Table 11 are consistent with those obtained using firm fixed effects.

Overall, the evidence supports significant positive firm valuation and productivity spillover effects following a cross-border M\&A. These results are also interesting given the difficulties in measuring productivity spillovers of FDI in prior studies (Aitken and Harrison (1999), Javorcik (2004), Haskel, Pereira, Slaughter (2007)). Our findings suggest that corporate governance spillovers are an important channel to explain firm valuation and productivity spillover effects.

\section{Conclusion}

We develop and test the hypothesis that cross-border M\&A activity in an industry leads to improvements in the corporate governance of the target firm's industry rivals. We find a positive relation between cross-border M\&A activity in an industry and corporate governance of non-target firms that operate in the same industry as the target firm. Crossborder M\&A activity is especially effective in improving corporate governance in more competitive industries and when the investor protection in the acquirer firm's country is stronger than the one in the target firm's country. Furthermore, cross-border M\&As lead to increases in firm valuation and productivity of non-target firms, suggesting that foreign direct

\footnotetext{
17 Although the $X V A L$ average effect is economically and statistically significant, the interaction term coefficients are estimated with less precision in the productivity regressions. This could be due to the fact that productivity is endogenous and therefore these tests lack power.

${ }^{18}$ We find similar spillovers effects of cross-border M\&A in competitive industries when using gross profits instead of sales as the numerator of the productivity measure when the acquirer firm country has higher investor protection than the target firm country.
} 
investment not only affects corporate governance mechanisms, but also has real effects on firm valuation and productivity.

Our findings establish a direct link between foreign direct investment and the adoption of practices that promote corporate accountability and empower shareholders worldwide. To our knowledge, our paper is the first to establish that the effect is not restricted to the target firm but spreads out to the target firm's industry rivals. Thus, foreign direct investment generates positive externalities across firms that operate in the target's industry. Our findings highlight that market forces, namely the international market for corporate control, are able to promote good corporate governance practices around the world. 


\section{APPENDix A}

This appendix solves a simple industry oligopoly model that offers economic intuition for our main hypotheses. Consider an industry composed of $N$ identical firms, labeled with subscript $i$. Outside shareholders and the manager of every firm are risk neutral. The model is static but has two decision stages. In the first stage, outside shareholders of firm $i$ choose firm level governance, $\phi_{i}$, given the $N-1$ governance choices of all other firms. In the second stage, given the governance choices, firm $i$ 's manager chooses private benefits, $s_{i}$, and the quantity to sell of output, $q_{i}$, given the choices of all other firms. Production entails a constant marginal cost of $c$. The equilibrium price, $p$, clears the market for the output. Letting $Q$ denote the aggregate supply of the output, the demand function is $p=a Q^{-1}$. This demand specification has negative unit elasticity, which makes it convenient analytically.

\section{Nash equilibrium}

We start by solving the second stage (the manager's problem). Firm $i$ 's manager's compensation is composed of a fixed component, $w_{0}$, an equity component of the managerial share holdings, $\alpha$, times firm profits, $\pi_{i}$, private benefits that may be captured at a cost (Shleifer and Wolfenzon (2002), La Porta, Lopez-de-Silanes, Shleifer, and Vishny (2002)):

$$
w_{0}+\alpha \pi_{i}+s_{i} p q_{i}-\phi_{i} \frac{s_{i}^{2}}{2} p q_{i}
$$

Following Albuquerque and Wang (2008), we model a quadratic cost of extracting private benefits. The cost associated with stealing depends on the level of governance, $\phi_{i}$.

Given the amount of private benefits, profits equal:

$$
\pi_{\mathrm{i}}=\left(1-\mathrm{s}_{\mathrm{i}}\right) \mathrm{pq}_{\mathrm{i}}-\mathrm{cq}_{\mathrm{i}}
$$

Managers choose $s_{i}$ and $q_{i}$ to maximize equation (A.1) subject to equation (A.2). The first order necessary and sufficient conditions are:

FOC for $s_{i}: \quad-\alpha p q_{i}+p q_{i}-\phi_{i} s_{i} p q_{i}=0$

FOC for $q_{i}: \quad \alpha\left(\left(1-s_{i}\right)\left(p+\frac{d p}{d q_{i}} q_{i}\right)-c\right)+s_{i}\left(p+\frac{d p}{d q_{i}} q_{i}\right)-\phi_{i} \frac{s_{i}^{2}}{2}\left(p+\frac{d p}{d q_{i}} q_{i}\right)=0$

The first of these conditions yields, $s_{i}=(1-\alpha) / \phi_{i}$. Private benefits are higher the lower is the manager's equity share and the lower is governance. We constrain parameters so that $s_{i}<1$. 
The second condition can be simplified by factorizing the term $p+\frac{d p}{d q_{i}} q_{i}$ :

$$
\left(\alpha\left(1-s_{i}\right)+s_{i}-\phi_{i} \frac{s_{i}^{2}}{2}\right)\left(p+\frac{d p}{d q_{i}} q_{i}\right)=\alpha c
$$

Noting that $p+\frac{d p}{d q_{i}} q_{i}=p\left(1-\frac{q_{i}}{Q}\right)$ and that $\alpha\left(1-s_{i}\right)+s_{i}-\phi_{i} \frac{s_{i}^{2}}{2}=\alpha+(1-\alpha) s_{i} / 2 \stackrel{\text { def }}{=} \bar{\alpha}_{i}$, this equation can be solved to yield:

$$
\mathrm{q}_{\mathrm{i}}=\mathrm{Q}-\frac{\alpha \mathrm{c}}{\bar{\alpha}_{\mathrm{i} a}} \mathrm{Q}^{2}
$$

In this model, with $\bar{\alpha}_{i}>\alpha$, firms produce more when their governance is weaker. The intuition for this result follows from Albuquerque and Wang (2008). Because private benefits are derived from revenues, managers have incentives to sell more. Because all other firms are also producing more, this behavior generates an externality where overall production increases. This "overproduction" story is consistent with evidence of overinvestment (see Harford (1999), Gompers, Ishii, and Metrick (2003), Philippon (2006)).

Having solved the firm manager's problem, we can now determine the symmetric equilibrium outcome. Since $Q=q_{1}+\cdots+q_{N}$, equation (A.3) yields the solution to aggregate industry supply $Q=\frac{N-1}{\sum_{i=1}^{N} \frac{\alpha c}{\bar{\alpha}_{i} a}}$, and prices are, $p=\frac{1}{N-1} \sum_{i=1}^{N} \frac{\alpha c}{\bar{\alpha}_{i} a}$.

We now turn to the equilibrium in the first stage (the outside shareholder's governance choice problem). Outside shareholders maximize their share of profits net of wages and of the cost of improving governance, which we model as $d \eta^{-1} \phi_{i}^{\eta}$, where $d$ is a scale parameter and $\eta$ describes how fast the cost of changing governance increases as governance improves:

$$
\max _{\phi_{i}}\left\{(1-\alpha)\left[\left(1-s_{i}\right) p q_{i}-c q_{i}\right]-w_{0}-d \eta^{-1} \phi_{i}^{\eta}\right\} \text {. }
$$

It is convenient to rewrite the optimization in terms of $s_{i}$ and replace $\phi_{i}=(1-\alpha) / s_{i}$. The necessary and sufficient first order condition for $s_{i}$ is

$$
-(1-\alpha) p q_{i}+d(1-\alpha)^{\eta} s_{i}^{-\eta-1}=0
$$

This first order condition presumes that managers disregard their choice of governance on second stage prices and quantities. While these may be nontrivial effects, they are likely to cancel each other with regards to their effect on revenues since better governance lowers quantities and increases prices. To keep the model simple and to be able to derive an intuition for our results, we ignore these effects.

In a symmetric first stage equilibrium, $s_{1}=\cdots=s_{N}=s^{*}$, which then leads to $q_{1}=\cdots=$ $q_{N}=q^{*}$, with $q^{*}=\frac{N-1}{N^{2}} \frac{\bar{\alpha} a}{\alpha c}, p^{*}=\frac{N}{N-1} \frac{\alpha c}{\bar{\alpha}}$, with 


$$
s^{*}=\left(\frac{d}{a} N(1-\alpha)^{\eta-1}\right)^{1 /(\eta+1)}
$$

When costs of adopting stronger governance increase, i.e., $d$ increases, governance decreases and private benefits increase. However, if the demand parameter, $a$, increases, the benefits of improving governance increase and private benefits decrease. These two effects are proportional to each other. More ex ante competition, i.e., higher $N$, decreases the ability to extract private benefits and thus decreases the incentives to improve governance.

\section{Spillover effects of a cross-border $M \& A$}

To model the effects of a cross-border acquisition, we assume that a firm, labeled with subscript " $f$ ", is the target firm of a cross-border M\&A and that the acquirer firm imposes better governance $\left(s_{f}<s^{*}\right)$. We label all other firms with a subscript "l" for local. Repeating the calculations for the second stage equilibrium private benefits and quantities, we find from

equation (A.3) that $q_{l}=Q-\frac{\alpha c}{\bar{\alpha}_{l} a} Q^{2}$, and $q_{f}=Q-\frac{\alpha c}{\bar{\alpha}_{f} a} Q^{2}$, and that the equilibrium output price is $p^{*}=\frac{\alpha c}{\bar{\alpha}_{l}}+\frac{1}{N-1} \frac{\alpha c}{\bar{\alpha}_{f}}$.

In the first stage, we solve only for governance of the local firms since the target firm exogenously changed its governance. Note that revenues for the local firms are $p q_{l}=a-$ $\frac{\alpha c}{\bar{\alpha}_{l}} Q$. The first order condition for governance for a target firm's local rival is as in equation (A.4), but where we replace $Q=(N-1) q_{l}+q_{f}$, and yields the implicit solution for $s_{l}$ :

$$
\frac{d}{a}(1-\alpha)^{\eta-1}=s_{l}^{\eta+1}\left(1-\frac{N-1}{N-1+\frac{\bar{\alpha}_{l}}{\bar{\alpha}_{f}}}\right)
$$

We can now derive our two main results. First, using the implicit function theorem and after some algebra:

$$
\frac{\partial s_{l}}{\partial s_{f}}=\frac{1}{2}(1-\alpha) \frac{(N-1) \bar{\alpha}_{l}}{(N-1) \bar{\alpha}_{f}+\bar{\alpha}_{l}} \frac{s_{l}}{(\eta+1) \bar{\alpha}_{l}+(N-1)\left(\bar{\alpha}_{l}-\alpha\right)}>0 .
$$

Better governance imposed on the target firm, i.e., lower $s_{f}$, leads to lower private benefits in the remaining local firms i.e., lower $s_{l}$. Intuitively, when the target firm improves its governance, and thus optimally reduces overproduction, more rents can be extracted by local rival firms in the oligopoly. These additional rents increase the marginal benefit to improving governance, otherwise more is taken away in the form of private benefits. This provides our first testable hypothesis: 
Hypothesis 1: Following a cross-border M\&A from a high governance acquirer firm, we expect non-target local firms operating in the same industry to improve their governance.

Next, we consider the effect of product market competition, i.e., higher $N$, on $\frac{\partial s_{l}}{\partial \bar{\alpha}_{f}}$. The function $\frac{\partial s_{l}}{\partial s_{f}}$ depends on $s_{l}$ and on $N$. Ignoring the indirect effect through $s_{l}$, it can be shown that $\frac{\partial^{2} s_{l}}{\partial N \partial s_{f}}>0$. That is, higher industry competition increases the responsiveness of governance in the industry with the cross-border M\&A. The intuition is that when governance improves in a firm and more rents are available to other firms, it pays off to improve governance, and this effect is more pronounced if governance is low, which is true with high $N .{ }^{19}$

Hypothesis 2: Following a cross-border M\&A from a high governance acquirer firm, we expect the positive spillover to the governance of non-target local firms to be higher in industries with high competition.

\footnotetext{
${ }^{19}$ The result that governance is low for high $N$ (i.e., in competitive industries) is in line with the evidence in Giroud and Mueller (2011) that show that firms in less competitive industries benefit more from good governance than do firms in competitive industries.
} 


\section{APPENDIX B}

Table B1

Variable definitions

\begin{tabular}{|c|c|}
\hline Variable & Definition \\
\hline GOV41 & $\begin{array}{l}\text { Firm-level index of corporate governance based on } 41 \text { attributes on board, audit, anti-takeover provisions, and compensation and ownership } \\
\text { structure (RiskMetrics). See Table B2 for details. }\end{array}$ \\
\hline$X V A L$ & $\begin{array}{l}\text { Value of cross-border M\&As (SDC Platinum) divided by market capitalization (Worldscope item 08001) in a country-industry (two-digit SIC } \\
\text { level). }\end{array}$ \\
\hline SIZE & Log of total assets in thousands of U.S. dollars (Worldscope item 02999). \\
\hline SGROWTH & Two-year geometric average of annual growth rate in sales in U.S.dollars (Worldscope item 01001). \\
\hline LEVERAGE & Total debt (Worldscope item 03255) divided by total assets (Worldscope item 02999). \\
\hline CASH & Cash and short-term investments (Worldscope item 02001) divided by total assets (Worldscope item 02999). \\
\hline CAPEX & Capital expenditures (Worldscope item 04601) divided by total assets (Worldscope item 02999). \\
\hline$M B$ & Market value of equity (Worldscope item 08001) divided by book value of equity (Worldscope item 03501 ). \\
\hline$R O A$ & $\begin{array}{l}\text { Ratio of net income before extraordinary items (Worldscope item 01551) plus interest expenses (Worldscope item 01151) to total assets } \\
\text { (Worldscope item 02999). }\end{array}$ \\
\hline$R \& D$ & Research and development expenditures (Worldscope item 01201) divided by total assets (Worldscope item 02999). \\
\hline$P P E$ & Property, plant, and equipment (Worldscope item 02501) divided by total assets (Worldscope item 02999). \\
\hline FXSALES & International sales (Worldscope item 07101) as a proportion of sales (Worldscope item 01001). \\
\hline ANALYST & Number of analysts following a firm (IBES). \\
\hline CLOSE & $\begin{array}{l}\text { Number of shares held by insiders (shareholders who hold five percent or more of the outstanding shares, such as officers, directors, and } \\
\text { immediate families, other corporations or individuals), as a fraction of the number of shares outstanding (Worldscope item } 08021 \text { ). }\end{array}$ \\
\hline$A D R$ & $\begin{array}{l}\text { Dummy that equals one if a firm is cross-listed on a U.S. exchange through a level 2-3 ADR or ordinary listing, and zero otherwise (major } \\
\text { depositary institutions and U.S. stock exchanges). }\end{array}$ \\
\hline IO_TOTAL & Holdings byinstitutional investors as a fraction of market capitalization (FactSet/LionShares). \\
\hline$D M A$ & Dummy that takes the value one if there is at least one domestic M\&A deal in a country-industry. \\
\hline IP & $\begin{array}{l}\text { Dummy variable that takes the value of one if the value-weighted average (weights are value of transaction) difference between acquirer and } \\
\text { target's country-level strenght of investor protection (World Economic Forum) in a given country-industry (two-digit SIC) is positive, and } \\
\text { zero otherwise. }\end{array}$ \\
\hline$H H I$ & Herfindahl-Hirschman index of the market shares in a country-industry using sales (Worldscope item 01001). \\
\hline IMP & Import penetration, defined as imports (United Nations Comtrade) over sales (Worldscope item 01001) in a country-industry (two-digit SIC). \\
\hline PRODK & Log of the ratio of sales (Worldscope item 01001) to property, plant, and equipment (Worldscope item 02501). \\
\hline EMPLOYEES & Log of total number of employees (Worldscope item 07011). \\
\hline
\end{tabular}




\section{Table B2}

\section{Firm-Level Governance Attributes}

\begin{tabular}{ll}
\hline & Panel A: Board \\
\hline 1 & All directors attended 75\% of board meetings or had a valid excuse \\
2 & CEO serves on the boards of two or fewer public companies \\
3 & Board is controlled by more than 50\% independent outside directors \\
4 & Board size is at greater than five but less than sixteen \\
5 & CEO is not listed as having a related-party transaction \\
6 & Compensation committee composed solely of independent outsiders \\
7 & Chairman and CEO positions are separated, or there is a lead director \\
8 & Nominating committee composed solely of independent outsiders \\
9 & Governance committee exists and met in the past year \\
10 & Shareholders vote on directors selected to fill vacancies \\
11 & Governance guidelines are publicly disclosed \\
12 & Annually elected board (no staggered board) \\
13 & Policy exists on outside directorships (four or fewer boards is the limit) \\
14 & Shareholders have cumulative voting rights \\
15 & Shareholder approval is required to increase/decrease board size \\
16 & Majority vote requirement to amend charter/bylaws (not supermajority) \\
17 & Board has the express authority to hire its own advisers \\
18 & Performance of the board is reviewed regularly \\
19 & Board-approved succession plan in place for the CEO \\
20 & Outside directors meet without CEO and disclose number of times met \\
21 & Directors are required to submit resignation upon a change in job \\
22 & Board cannot amend bylaws without shareholder approval or can do so only under limited circumstances \\
23 & Does not ignore shareholder proposal \\
24 & Qualifies for proxy contest defenses combination points \\
\hline
\end{tabular}

25 Consulting fees paid to auditors are less than audit fees paid to auditors

26 Audit committee composed solely of independent outsiders

27 Auditors ratified at most recent annual meeting

\section{Panel C: Anti-takeover provisions}

28 Single class, common

29 Majority vote requirement to approve mergers (not supermajority)

30 Shareholders may call special meetings

31 Shareholders may act by written consent

32 Company either has no poison pill or a pill that is shareholder approved.

33 Company is not authorized to issue blank check preferred

Panel D: Compensation and ownership

34 Directors are subject to stock ownership requirements

35 Executives are subject to stock ownership guidelines

36 No interlocks among compensation committee members

37 Directors receive all or a portion of their fees in stock

38 All stock-incentive plans adopted with shareholder approval

39 Options grants align with company performance and reasonable burn rate

40 Officers' and directors' stock ownership is at least $1 \%$ but not over $30 \%$ of total shares outstanding

41 Repricing prohibited 


\section{REFERENCES}

Acharya, V., and P. Volpin, 2010, "Corporate Governance Externalities," Review of Finance 14, pp. 1-33.

Aggarwal, R., I. Erel, R. Stulz, and R. Williamson, 2009, "Differences in Governance Practices between U.S. and Foreign Firms: Measurement, Causes, and Consequences," Review of Financial Studies 22, pp. 3131-3169.

Aggarwal, R., I. Erel, M. Ferreira, P. Matos, 2011, "Does Governance Travel Around the World? Evidence from institutional investors," Journal of Financial Economics 100, pp. 154-181.

Aitken, B., and A. Harrison, 1999, "Do Domestic Firms Benefit from Direct Foreign Investment? Evidence from Venezuela," American Economic Review 89, p. 605-618.

Albuquerque, R., and N. Wang, 2008, "Agency Conflicts, Investment, and Asset Pricing," Journal of Finance 63, pp. 1-40.

Bloomberg, 2012, "Fourth-Quarter M\&A Surge Spurs Optimism after 2012 Deals Decline."

Bris, A., and C. Cabolis, 2008, "the Value of investor Protection: Firm Evidence from CrossBorder Mergers," Review of Financial Studies 21, pp. 605-648.

Bris, A., N. Brisley, and C. Cabolis, 2008, "Adopting Better Corporate Governance: Evidence from Cross-Border Mergers," Journal of Corporate Finance 14, pp. 224-240.

Cheng, I.-H., 2010, “Corporate Governance Spillovers,” Working Paper, University of Michigan.

Dicks, David L., 2012, "Executive Compensation and the Role for Corporate Governance Regulation," Review of Financial Studies 25, pp. 1971-2004.

Djankov, S., R. La Porta, F. Lopez-De-Silanes, and A. Shleifer, 2008, "The Law and Economics of Self-Dealing," Journal of Financial Economics 88, pp. 430-465.

Doidge, C., G. A. Karolyi, R. Stulz, 2004, "Why Are Foreign Firms Listed in the US Worth More?” Journal of Financial Economics 71, pp. 205-238.

Economist, 2007, "The Global Merger Boom: The Beat Goes On."

Fernandes, N., 2009, 'Market Liberalizations at the Firm Level: Spillovers from ADRs and Implications for Local Markets," Journal of international Money and Finance 28, pp. 293-321.

Giroud, X., and H. Mueller, 2011, "Corporate Governance, Product Market Competition, and Equity Prices," Journal of Finance 66, pp. 563-600.

Gompers, P., J. Ishii, and A. Metrick, 2003, "Corporate Governance and Equity Prices," Quarterly Journal of Economics 118, pp. 107-156.

Haddad, M., and A. Harrison, 1993, "Are There Positive Spillovers from Direct Foreign Investment? Evidence from Panel Data for Morocco," Journal of Development Economics 42, pp. 51-74. 
Harford, J., 1999, "Corporate Cash Reserves and Acquisitions," Journal of Finance 54, pp. 1969-1997.

Haskel, J., S. Pereira, and M. Slaughter, 2007, "Does Inward Foreign Direct Investment Boost the Productivity of Domestic Firms?" Review of Economics and Statistics 89, pp. 482-496.

Javorcik, B., 2004, "Does Foreign Direct Investment increase the Productivity of Domestic Firms?" in Search of Spillovers through Backward Linkages, American Economic Review 94, pp. 605-627.

La Porta, R., F. Lopez-De-Silanes, A. Shleifer, and R. Vishny, 1998, "Law and Finance," Journal of Political Economy 106, pp. 1113-1155.

La Porta, R., F. Lopez-De-Silanes, A. Shleifer, and R. Vishny, 2002, "Investor Protection and Corporate Valuation," Journal of Finance 57, pp. 1147-1170.

Levit, D., and N. Malenko, 2013, “The Labor Market for Directors and Externalities in Corporate Governance," Working Paper, University of Pennsylvania.

Martynova M., and L. Renneboog, 2008, "Spillover of Corporate Governance Standards in Cross-Border Mergers and Acquisitions," Journal of Corporate Finance 14, pp. 200-223.

Organization For Economic Co-Operation and Development, 2007, "International Investment Perspectives: Freedom of Investment in a Changing World."

Philippon, T., 2006, "Corporate Governance over the Business Cycle," Journal of Economic Dynamics and Control 30, pp. 2117-2141.

Rossi, S., and P. Volpin, 2004, "Cross-Country Determinants of Mergers and Acquisitions," Journal of Financial Economics 74, pp. 277-304.

Servaes, H., and A. Tamayo, 2012, "How Do industry Peers Respond to Control Threats?" Management Science, Forthcoming.

Shleifer, A., and D. Wolfenzon, 2002, "Investor Protection and Equity Markets," Journal of Financial Economics 66, pp. 3-27.

Syverson, C., 2011, "What Determines Productivity?" Journal of Economic Literature 49, pp. 326-365. 
Table 1 - Corporate Governance and Cross-Border M\&A by Target Country

This table shows the mean and standard deviation of the corporate governance index (GOV41) and annual transaction value of cross-border M\&As in a firm's country-industry as a fraction of market capitalization (XVAL). The sample consists of Worldscope firms for which GOV41 data are available in the 2004-2008 period.

\begin{tabular}{|c|c|c|c|c|c|c|}
\hline \multirow[b]{2}{*}{ Country } & \multirow[b]{2}{*}{$\begin{array}{l}\text { Number } \\
\text { of firms }\end{array}$} & \multirow[b]{2}{*}{$\begin{array}{c}\text { Number of } \\
\text { observations }\end{array}$} & \multicolumn{2}{|c|}{ GOV41 } & \multicolumn{2}{|c|}{$X V A L$} \\
\hline & & & Mean & $\begin{array}{r}\text { Standard } \\
\text { deviation }\end{array}$ & Mean & $\begin{array}{r}\text { Standard } \\
\text { deviation }\end{array}$ \\
\hline Australia & 119 & 495 & 0.472 & 0.064 & 0.036 & 0.134 \\
\hline Austria & 18 & 86 & 0.421 & 0.057 & 0.020 & 0.049 \\
\hline Belgium & 27 & 124 & 0.355 & 0.079 & 0.046 & 0.264 \\
\hline Canada & 188 & 797 & 0.670 & 0.073 & 0.060 & 0.405 \\
\hline Denmark & 22 & 103 & 0.420 & 0.064 & 0.022 & 0.052 \\
\hline Finland & 30 & 142 & 0.504 & 0.083 & 0.000 & 0.000 \\
\hline France & 86 & 403 & 0.435 & 0.070 & 0.020 & 0.078 \\
\hline Germany & 90 & 411 & 0.453 & 0.064 & 0.032 & 0.083 \\
\hline Greece & 43 & 202 & 0.337 & 0.069 & 0.017 & 0.088 \\
\hline Hong Kong & 66 & 278 & 0.432 & 0.058 & 0.013 & 0.034 \\
\hline Ireland & 17 & 76 & 0.480 & 0.082 & 0.011 & 0.032 \\
\hline Italy & 72 & 305 & 0.409 & 0.064 & 0.028 & 0.126 \\
\hline Japan & 599 & 2,845 & 0.377 & 0.032 & 0.001 & 0.013 \\
\hline Netherlands & 46 & 204 & 0.472 & 0.103 & 0.071 & 0.584 \\
\hline New Zealand & 16 & 68 & 0.456 & 0.044 & 0.011 & 0.030 \\
\hline Norway & 24 & 106 & 0.398 & 0.079 & 0.120 & 0.564 \\
\hline Portugal & 14 & 69 & 0.352 & 0.047 & 0.007 & 0.020 \\
\hline Singapore & 60 & 278 & 0.448 & 0.071 & 0.020 & 0.050 \\
\hline Spain & 57 & 250 & 0.437 & 0.076 & 0.039 & 0.107 \\
\hline Sweden & 48 & 207 & 0.434 & 0.095 & 0.045 & 0.103 \\
\hline Switzerland & 61 & 280 & 0.504 & 0.095 & 0.011 & 0.022 \\
\hline United Kingdom & 520 & 2,088 & 0.532 & 0.075 & 0.150 & 1.201 \\
\hline Total & 2,223 & 9,817 & 0.460 & 0.108 & 0.050 & 0.581 \\
\hline
\end{tabular}




\section{Table 2 - Corporate Governance and Cross-Border M\&A by Industry}

This table shows the mean and standard deviation of the corporate governance index (GOV41) and annual transaction value of cross-border M\&As in the firm's country-industry as a fraction of market capitalization (XVAL). The sample consists of Worldscope non-target firms for which GOV41 data are available in the 2004-2008 period. Panel A reports the top ten industries in terms of XVAL and Panel B reports the bottom ten industries in terms of XVAL.

Panel A: Top ten industries

\begin{tabular}{|c|c|c|c|c|c|}
\hline \multirow[b]{2}{*}{ Industry } & \multirow[b]{2}{*}{$\begin{array}{l}\text { Number of } \\
\text { observations }\end{array}$} & \multicolumn{2}{|c|}{ GOV41 } & \multicolumn{2}{|c|}{$X V A L$} \\
\hline & & Mean & $\begin{array}{l}\text { Standard } \\
\text { deviation }\end{array}$ & Mean & $\begin{array}{r}\text { Standard } \\
\text { deviation }\end{array}$ \\
\hline Transportation services & 68 & 0.452 & 0.076 & 2.058 & 6.304 \\
\hline Construction-special trade contractors & 13 & 0.454 & 0.076 & 1.095 & 2.640 \\
\hline Health services & 42 & 0.488 & 0.096 & 0.223 & 0.519 \\
\hline Motion pictures & 37 & 0.459 & 0.104 & 0.221 & 0.470 \\
\hline Stone clay glass \& concrete prods & 182 & 0.452 & 0.086 & 0.214 & 0.821 \\
\hline Insurance agents brokers \& service & 16 & 0.486 & 0.081 & 0.195 & 0.328 \\
\hline Real estate & 251 & 0.450 & 0.103 & 0.160 & 0.210 \\
\hline Social services & 9 & 0.575 & 0.063 & 0.120 & 0.271 \\
\hline Hotels rooming houses \& camps & 100 & 0.470 & 0.097 & 0.119 & 0.221 \\
\hline Primary metal industries & 216 & 0.434 & 0.089 & 0.113 & 0.682 \\
\hline
\end{tabular}

Panel B: Bottom ten industries

\begin{tabular}{|c|c|c|c|c|c|}
\hline \multirow[b]{2}{*}{ Industry } & \multirow[b]{2}{*}{$\begin{array}{c}\text { Number of } \\
\text { observations }\end{array}$} & \multicolumn{2}{|c|}{ GOV41 } & \multicolumn{2}{|c|}{ XVAL } \\
\hline & & Mean & $\begin{array}{r}\text { Standard } \\
\text { deviation }\end{array}$ & Mean & $\begin{array}{r}\text { Standard } \\
\text { deviation }\end{array}$ \\
\hline Petroleum refining \& related industries & 78 & 0.485 & 0.145 & 0.000 & 0.001 \\
\hline Building materials \& hardware & 26 & 0.520 & 0.132 & 0.000 & 0.002 \\
\hline Administration of economic programs & 5 & 0.463 & 0.075 & 0.000 & 0.000 \\
\hline Leather \& leather products & 5 & 0.361 & 0.065 & 0.000 & 0.000 \\
\hline National security \& international affairs & 4 & 0.476 & 0.061 & 0.000 & 0.000 \\
\hline Apparel \& accessory stores & 73 & 0.450 & 0.080 & 0.002 & 0.004 \\
\hline Railroad transportation & 44 & 0.498 & 0.155 & 0.002 & 0.016 \\
\hline Fishing hunting \& trapping & 9 & 0.388 & 0.051 & 0.002 & 0.005 \\
\hline Heavy construction except building & 153 & 0.409 & 0.081 & 0.003 & 0.024 \\
\hline Food Stores & 149 & 0.461 & 0.117 & 0.003 & 0.010 \\
\hline
\end{tabular}


Table 3 - Summary Statistics

The table shows mean, median, standard deviation, minimum, maximum, and number of observations for each variable. The sample consists of Worldscope firms for which GOV41 data are available in the 2004-2008 period. Variable definitions are provided in Table B1 in the Appendix.

\begin{tabular}{lcccccc}
\hline Variable & Mean & Median & $\begin{array}{c}\text { Standard } \\
\text { deviation }\end{array}$ & Minimum & Maximum & $\begin{array}{c}\text { Number of } \\
\text { observations }\end{array}$ \\
\hline GOV41 & 0.460 & 0.439 & 0.108 & 0.195 & 0.878 & 9,817 \\
XVAL & 0.050 & 0.001 & 0.581 & 0.000 & 28.672 & 9,816 \\
SIZE & 14.598 & 14.579 & 2.237 & 5.347 & 22.052 & 9,221 \\
SGROWTH & 0.167 & 0.126 & 0.304 & -0.661 & 2.232 & 9,012 \\
LEVERAGE & 0.235 & 0.219 & 0.190 & 0.000 & 1.319 & 9,220 \\
CASH & 0.138 & 0.090 & 0.150 & 0.000 & 0.998 & 8,330 \\
CAPEX & 0.047 & 0.034 & 0.051 & 0.000 & 0.313 & 9,040 \\
MB & 2.501 & 1.842 & 2.444 & -1.870 & 15.969 & 9,418 \\
ROA & 0.047 & 0.054 & 0.126 & -1.766 & 0.325 & 9,095 \\
R\&D & 0.014 & 0.000 & 0.044 & 0.000 & 0.629 & 9,817 \\
PPE & 0.289 & 0.237 & 0.250 & 0.000 & 0.996 & 9,197 \\
FXSALES & 0.319 & 0.209 & 0.337 & 0.000 & 0.996 & 9,817 \\
ANALYST & 8.017 & 6.000 & 7.884 & 0.000 & 48.000 & 9,817 \\
CLOSE & 0.348 & 0.314 & 0.250 & 0.000 & 1.000 & 8,471 \\
ADR & 0.133 & 0.000 & 0.340 & 0.000 & 1.000 & 9,817 \\
IO_TOTAL & 0.214 & 0.147 & 0.233 & 0.000 & 1.000 & 9,817 \\
DMA & 0.804 & 1.000 & 0.397 & 0.000 & 1.000 & 9,817 \\
IP & 0.398 & 0.000 & 0.490 & 0.000 & 1.000 & 9,817 \\
HHI & 0.278 & 0.197 & 0.248 & 0.000 & 1.000 & 9,805 \\
IMP & 1.172 & 0.000 & 3.852 & 0.000 & 27.226 & 10,069 \\
PRODK & 1.367 & 1.350 & 1.415 & -2.581 & 5.038 & 10,264 \\
EMPLOYEES & 8.614 & 8.660 & 1.722 & 1.386 & 13.277 & 9,732 \\
\hline
\end{tabular}


Table 4 - Cross-Border M\&A and Non-Target Corporate Governance: Firm Fixed Effects

This table presents estimates of firm fixed effects panel regressions of the corporate governance index (GOV41) of non-target firms on the value of cross-border M\&A in a firm's country-industry as a fraction of market capitalization $(X V A L)$. Column (6) reports instrumental variables estimates in which import penetration (IMP) is used as an instrument for $X V A L$. Regressions include year fixed effects. All explanatory variables are lagged one year. The sample consists of Worldscope firms for which GOV41 data are available in the 2004-2008 period. Variable definitions are provided in Table B1 in the Appendix. Robust $p$-values adjusted for country-level clustering are reported in brackets. $*, * * * * *$ indicate significance at the $10 \%, 5 \%$ and $1 \%$ levels, respectively.

\begin{tabular}{|c|c|c|c|c|c|c|}
\hline & $(1)$ & $(2)$ & (3) & $(4)$ & $(5)$ & $(6)$ \\
\hline$X V A L$ & & $\begin{array}{c}0.0053 * * \\
(0.031)\end{array}$ & $\begin{array}{c}0.0026^{*} \\
(0.095)\end{array}$ & $\begin{array}{c}0.0165 * * \\
(0.035)\end{array}$ & $\begin{array}{c}0.0138^{* *} \\
(0.021)\end{array}$ & $\begin{array}{c}0.1011 * * \\
(0.046)\end{array}$ \\
\hline$I P$ & & & $\begin{array}{l}0.0020 \\
(0.443)\end{array}$ & & $\begin{array}{l}0.0013 \\
(0.641)\end{array}$ & \\
\hline$X V A L \times I P$ & & & $\begin{array}{c}0.0123 * * \\
(0.011)\end{array}$ & & $\begin{array}{c}0.0725 * * * \\
(0.009)\end{array}$ & \\
\hline$H H I$ & & & & $\begin{array}{c}-0.0062 \\
(0.820)\end{array}$ & $\begin{array}{c}-0.0054 \\
(0.837)\end{array}$ & \\
\hline$X V A L \times H H I$ & & & & $\begin{array}{c}-0.0240 * * \\
(0.049)\end{array}$ & $\begin{array}{c}-0.0253 * * \\
(0.048)\end{array}$ & \\
\hline$H H I \times I P$ & & & & & $\begin{array}{r}-0.0017 \\
(0.844)\end{array}$ & \\
\hline$X V A L \times H H I \times I P$ & & & & & $\begin{array}{c}-0.1001 * * \\
(0.028)\end{array}$ & \\
\hline SIZE & $\begin{array}{c}-0.0056 * \\
(0.097)\end{array}$ & $\begin{array}{c}-0.0054 \\
(0.108)\end{array}$ & $\begin{array}{c}-0.0054 \\
(0.110)\end{array}$ & $\begin{array}{c}-0.0053 \\
(0.112)\end{array}$ & $\begin{array}{c}-0.0053 \\
(0.110)\end{array}$ & $\begin{array}{c}-0.0045 \\
(0.225)\end{array}$ \\
\hline SGROWTH & $\begin{array}{c}-0.0011 \\
(0.686)\end{array}$ & $\begin{array}{r}-0.0010 \\
(0.701)\end{array}$ & $\begin{array}{r}-0.0010 \\
(0.701)\end{array}$ & $\begin{array}{r}-0.0009 \\
(0.719)\end{array}$ & $\begin{array}{r}-0.0009 \\
(0.724)\end{array}$ & $\begin{array}{l}0.0001 \\
(0.978)\end{array}$ \\
\hline LEVERAGE & $\begin{array}{l}0.0049 \\
(0.564)\end{array}$ & $\begin{array}{l}0.0044 \\
(0.601)\end{array}$ & $\begin{array}{l}0.0044 \\
(0.601)\end{array}$ & $\begin{array}{l}0.0044 \\
(0.599)\end{array}$ & $\begin{array}{l}0.0043 \\
(0.606)\end{array}$ & $\begin{array}{c}-0.0012 \\
(0.871)\end{array}$ \\
\hline CASH & $\begin{array}{r}-0.0149 \\
(0.199)\end{array}$ & $\begin{array}{c}-0.0151 \\
(0.195)\end{array}$ & $\begin{array}{r}-0.0150 \\
(0.202)\end{array}$ & $\begin{array}{r}-0.0149 \\
(0.202)\end{array}$ & $\begin{array}{c}-0.0144 \\
(0.224)\end{array}$ & $\begin{array}{c}-0.0181 \\
(0.127)\end{array}$ \\
\hline CAPEX & $\begin{array}{c}-0.0335 * \\
(0.052)\end{array}$ & $\begin{array}{c}-0.0318^{*} \\
(0.071)\end{array}$ & $\begin{array}{c}-0.0309 * \\
(0.091)\end{array}$ & $\begin{array}{c}-0.0319 * \\
(0.067)\end{array}$ & $\begin{array}{c}-0.0307 * \\
(0.095)\end{array}$ & $\begin{array}{r}-0.0179 \\
(0.347)\end{array}$ \\
\hline$M B$ & $\begin{array}{l}0.0001 \\
(0.839)\end{array}$ & $\begin{array}{l}0.0001 \\
(0.823)\end{array}$ & $\begin{array}{l}0.0001 \\
(0.801)\end{array}$ & $\begin{array}{l}0.0001 \\
(0.828)\end{array}$ & $\begin{array}{l}0.0001 \\
(0.751)\end{array}$ & $\begin{array}{l}0.0002 \\
(0.511)\end{array}$ \\
\hline$R O A$ & $\begin{array}{c}0.0200 * * * \\
(0.010)\end{array}$ & $\begin{array}{c}0.0197 * * \\
(0.011)\end{array}$ & $\begin{array}{c}0.0199 * * \\
(0.012)\end{array}$ & $\begin{array}{c}0.0198 * * \\
(0.012)\end{array}$ & $\begin{array}{c}0.0200^{* *} \\
(0.014)\end{array}$ & $\begin{array}{c}0.0157 * * \\
(0.011)\end{array}$ \\
\hline$R \& D$ & $\begin{array}{l}0.0393 \\
(0.531)\end{array}$ & $\begin{array}{l}0.0408 \\
(0.513)\end{array}$ & $\begin{array}{l}0.0424 \\
(0.498)\end{array}$ & $\begin{array}{l}0.0409 \\
(0.517)\end{array}$ & $\begin{array}{l}0.0448 \\
(0.469)\end{array}$ & $\begin{array}{l}0.0470 \\
(0.435)\end{array}$ \\
\hline$P P E$ & $\begin{array}{c}-0.0048 \\
(0.677)\end{array}$ & $\begin{array}{c}-0.0052 \\
(0.651)\end{array}$ & $\begin{array}{c}-0.0051 \\
(0.657)\end{array}$ & $\begin{array}{c}-0.0050 \\
(0.663)\end{array}$ & $\begin{array}{c}-0.0050 \\
(0.666)\end{array}$ & $\begin{array}{c}-0.0083 \\
(0.449)\end{array}$ \\
\hline FXSALES & $\begin{array}{c}-0.0003 \\
(0.944)\end{array}$ & $\begin{array}{c}-0.0003 \\
(0.957)\end{array}$ & $\begin{array}{c}-0.0003 \\
(0.948)\end{array}$ & $\begin{array}{c}-0.0002 \\
(0.972)\end{array}$ & $\begin{array}{c}-0.0004 \\
(0.934)\end{array}$ & $\begin{array}{l}0.0001 \\
(0.980)\end{array}$ \\
\hline ANALYST & $\begin{array}{l}0.0005 \\
(0.361)\end{array}$ & $\begin{array}{l}0.0005 \\
(0.372)\end{array}$ & $\begin{array}{l}0.0005 \\
(0.392)\end{array}$ & $\begin{array}{l}0.0005 \\
(0.385)\end{array}$ & $\begin{array}{l}0.0004 \\
(0.421)\end{array}$ & $\begin{array}{l}0.0004 \\
(0.465)\end{array}$ \\
\hline CLOSE & $\begin{array}{c}-0.0142 * * * \\
(0.007)\end{array}$ & $\begin{array}{c}-0.0141 * * * \\
(0.008)\end{array}$ & $\begin{array}{c}-0.0145^{* * *} \\
(0.006)\end{array}$ & $\begin{array}{c}-0.0140 * * * \\
(0.008)\end{array}$ & $\begin{array}{c}-0.0144 * * * \\
(0.006)\end{array}$ & $\begin{array}{c}-0.0141 * * * \\
(0.001)\end{array}$ \\
\hline$A D R$ & $\begin{array}{l}0.0202 \\
(0.335)\end{array}$ & $\begin{array}{l}0.0200 \\
(0.340)\end{array}$ & $\begin{array}{l}0.0199 \\
(0.345)\end{array}$ & $\begin{array}{c}0.0201 \\
(0.341)\end{array}$ & $\begin{array}{c}0.0203 \\
(0.338)\end{array}$ & $\begin{array}{c}0.0196 \\
(0.336)\end{array}$ \\
\hline IO_TOTAL & $\begin{array}{c}0.0253 * * \\
(0.024)\end{array}$ & $\begin{array}{c}0.0249 * * \\
(0.022)\end{array}$ & $\begin{array}{c}0.0247 * * \\
(0.020)\end{array}$ & $\begin{array}{c}0.0247 * * \\
(0.026)\end{array}$ & $\begin{array}{c}0.0244 * * \\
(0.023)\end{array}$ & $\begin{array}{c}0.0176^{* *} \\
(0.014)\end{array}$ \\
\hline$D M A$ & & $\begin{array}{r}-0.0033 \\
(0.371)\end{array}$ & $\begin{array}{c}-0.0024 \\
(0.454)\end{array}$ & $\begin{array}{r}-0.0033 \\
(0.365)\end{array}$ & $\begin{array}{r}-0.0031 \\
(0.397)\end{array}$ & $\begin{array}{r}-0.0028 \\
(0.439)\end{array}$ \\
\hline Number of observations & 7,398 & 7,398 & 7,398 & 7,384 & 7,384 & 7,293 \\
\hline R-squared & 0.875 & 0.875 & 0.875 & 0.875 & 0.876 & - \\
\hline
\end{tabular}




\section{Table 5 - Cross-Border M\&A and Non-Target Corporate Governance: First Differences}

This table presents estimates of first differences panel regressions of the corporate governance index $(G O V 41)$ of non-target firms on the value of cross-border M\&A in a firm's country-industry as a fraction of market capitalization $(X V A L)$. Regressions include country, industry and year fixed effects. All explanatory variables are lagged one year. The sample consists of Worldscope firms for which GOV41 data are available in the 2004-2008 period. Variable definitions are provided in Table B1 in the Appendix. Robust $p$-values adjusted for country-level clustering are reported in brackets. $* * *, * * *$ indicate significance at the $10 \%, 5 \%$ and $1 \%$ levels, respectively.

\begin{tabular}{|c|c|c|c|c|c|}
\hline & (1) & $(2)$ & (3) & (4) & (5) \\
\hline$\triangle X V A L$ & & $\begin{array}{c}0.0047 * * * \\
(0.008)\end{array}$ & $\begin{array}{c}0.0026 * \\
(0.062)\end{array}$ & $\begin{array}{c}0.0143 * \\
(0.061)\end{array}$ & $\begin{array}{c}0.0148 * * \\
(0.010)\end{array}$ \\
\hline$\Delta I P$ & & & $\begin{array}{l}0.0021 \\
(0.389)\end{array}$ & & $\begin{array}{l}-0.0011 \\
(0.663)\end{array}$ \\
\hline$\Delta(X V A L \times I P)$ & & & $\begin{array}{c}0.0117 * * \\
(0.047)\end{array}$ & & $\begin{array}{c}0.0579 * \\
(0.069)\end{array}$ \\
\hline$\Delta H H I$ & & & & $\begin{array}{c}-0.0088 \\
(0.623)\end{array}$ & $\begin{array}{r}-0.0137 \\
(0.451)\end{array}$ \\
\hline$\Delta(X V A L \times H H I)$ & & & & $\begin{array}{c}-0.0211 \\
(0.125)\end{array}$ & $\begin{array}{c}-0.0276^{* * * *} \\
(0.008)\end{array}$ \\
\hline$\Delta(H H I \times I P)$ & & & & & $\begin{array}{c}0.0109 * * \\
(0.047)\end{array}$ \\
\hline$\Delta(X V A L \times H H I \times I P)$ & & & & & $\begin{array}{c}-0.0763 \\
(0.144)\end{array}$ \\
\hline$\triangle S I Z E$ & $\begin{array}{c}-0.0087 * * * \\
(0.001)\end{array}$ & $\begin{array}{c}-0.0088^{* * * *} \\
(0.001)\end{array}$ & $\begin{array}{c}-0.0089 * * * \\
(0.001)\end{array}$ & $\begin{array}{c}-0.0087 * * * \\
(0.001)\end{array}$ & $\begin{array}{c}-0.0087 * * * \\
(0.002)\end{array}$ \\
\hline$\triangle S G R O W T H$ & $\begin{array}{l}-0.0026 \\
(0.373)\end{array}$ & $\begin{array}{r}-0.0027 \\
(0.371)\end{array}$ & $\begin{array}{l}-0.0027 \\
(0.369)\end{array}$ & $\begin{array}{l}-0.0027 \\
(0.371)\end{array}$ & $\begin{array}{l}-0.0026 \\
(0.374)\end{array}$ \\
\hline$\triangle L E V E R A G E$ & $\begin{array}{l}0.0072 \\
(0.454)\end{array}$ & $\begin{array}{l}0.0065 \\
(0.496)\end{array}$ & $\begin{array}{l}0.0071 \\
(0.460)\end{array}$ & $\begin{array}{l}0.0061 \\
(0.521)\end{array}$ & $\begin{array}{l}0.0062 \\
(0.513)\end{array}$ \\
\hline$\triangle C A S H$ & $\begin{array}{l}-0.0148 \\
(0.145)\end{array}$ & $\begin{array}{c}-0.0153 \\
(0.127)\end{array}$ & $\begin{array}{l}-0.0153 \\
(0.128)\end{array}$ & $\begin{array}{l}-0.0155 \\
(0.124)\end{array}$ & $\begin{array}{c}-0.0156 \\
(0.120)\end{array}$ \\
\hline$\triangle C A P E X$ & $\begin{array}{c}-0.0264 \\
(0.117)\end{array}$ & $\begin{array}{r}-0.0245 \\
(0.148)\end{array}$ & $\begin{array}{l}-0.0250 \\
(0.143)\end{array}$ & $\begin{array}{l}-0.0247 \\
(0.148)\end{array}$ & $\begin{array}{l}-0.0263 \\
(0.129)\end{array}$ \\
\hline$\Delta M B$ & $\begin{array}{l}-0.0001 \\
(0.829)\end{array}$ & $\begin{array}{l}-0.0001 \\
(0.679)\end{array}$ & $\begin{array}{l}-0.0001 \\
(0.725)\end{array}$ & $\begin{array}{l}-0.0001 \\
(0.665)\end{array}$ & $\begin{array}{r}-0.0001 \\
(0.783)\end{array}$ \\
\hline$\triangle R O A$ & $\begin{array}{c}0.0168 * * \\
(0.024)\end{array}$ & $\begin{array}{c}0.0174 * * \\
(0.029)\end{array}$ & $\begin{array}{c}0.0175^{* *} \\
(0.024)\end{array}$ & $\begin{array}{c}0.0178^{* *} \\
(0.029)\end{array}$ & $\begin{array}{c}0.0177 * * \\
(0.025)\end{array}$ \\
\hline$\Delta R \& D$ & $\begin{array}{c}-0.0196 \\
(0.676)\end{array}$ & $\begin{array}{c}-0.0165 \\
(0.746)\end{array}$ & $\begin{array}{l}-0.0167 \\
(0.745)\end{array}$ & $\begin{array}{c}-0.0163 \\
(0.748)\end{array}$ & $\begin{array}{l}-0.0167 \\
(0.747)\end{array}$ \\
\hline$\triangle P P E$ & $\begin{array}{r}-0.0065 \\
(0.594)\end{array}$ & $\begin{array}{r}-0.0083 \\
(0.507)\end{array}$ & $\begin{array}{l}-0.0079 \\
(0.520)\end{array}$ & $\begin{array}{c}-0.0084 \\
(0.504)\end{array}$ & $\begin{array}{r}-0.0077 \\
(0.528)\end{array}$ \\
\hline$\triangle F X S A L E S$ & $\begin{array}{l}-0.0001 \\
(0.991)\end{array}$ & $\begin{array}{l}0.0001 \\
(0.985)\end{array}$ & $\begin{array}{l}0.0000 \\
(0.996)\end{array}$ & $\begin{array}{l}0.0003 \\
(0.945)\end{array}$ & $\begin{array}{l}0.0003 \\
(0.948)\end{array}$ \\
\hline$\triangle A N A L Y S T$ & $\begin{array}{r}-0.0001 \\
(0.748)\end{array}$ & $\begin{array}{c}-0.0002 \\
(0.665)\end{array}$ & $\begin{array}{l}-0.0002 \\
(0.653)\end{array}$ & $\begin{array}{r}-0.0002 \\
(0.635)\end{array}$ & $\begin{array}{l}-0.0002 \\
(0.582)\end{array}$ \\
\hline$\triangle C L O S E$ & $\begin{array}{c}-0.0151 * * * \\
(0.003)\end{array}$ & $\begin{array}{c}-0.0154 * * * \\
(0.002)\end{array}$ & $\begin{array}{c}-0.0154 * * * \\
(0.002)\end{array}$ & $\begin{array}{c}-0.0159 * * * \\
(0.002)\end{array}$ & $\begin{array}{c}-0.0156 * * * \\
(0.001)\end{array}$ \\
\hline$\triangle A D R$ & $\begin{array}{c}0.0195 * * \\
(0.024)\end{array}$ & $\begin{array}{c}0.0195 * * \\
(0.024)\end{array}$ & $\begin{array}{c}0.0192 * * \\
(0.024)\end{array}$ & $\begin{array}{c}0.0195 * * \\
(0.023)\end{array}$ & $\begin{array}{c}0.0188 * * \\
(0.027)\end{array}$ \\
\hline$\triangle I O \_T O T A L$ & $\begin{array}{c}0.0175^{*} \\
(0.062)\end{array}$ & $\begin{array}{c}0.0165 * * \\
(0.048)\end{array}$ & $\begin{array}{c}0.0166^{* *} \\
(0.048)\end{array}$ & $\begin{array}{c}0.0162 * \\
(0.052)\end{array}$ & $\begin{array}{c}0.0163 * \\
(0.051)\end{array}$ \\
\hline$\triangle D M A$ & & $\begin{array}{l}-0.0030 \\
(0.331)\end{array}$ & $\begin{array}{l}-0.0021 \\
(0.502)\end{array}$ & $\begin{array}{l}-0.0031 \\
(0.315)\end{array}$ & $\begin{array}{l}-0.0015 \\
(0.611)\end{array}$ \\
\hline $\begin{array}{l}\text { Number of observations } \\
\text { R-squared }\end{array}$ & $\begin{array}{l}5,529 \\
0.209\end{array}$ & $\begin{array}{l}5,484 \\
0.210\end{array}$ & $\begin{array}{l}5,484 \\
0.211\end{array}$ & $\begin{array}{l}5,473 \\
0.210\end{array}$ & $\begin{array}{l}5,473 \\
0.212\end{array}$ \\
\hline
\end{tabular}




\section{Table 6 - Cross-Border M\&A and Non-Target Corporate Governance: Robustness}

This table presents estimates of firm fixed effects panel regressions of the corporate governance index (GOV41) of non-target firms on the value of cross-border M\&A in a firm's country-industry as a fraction of market capitalization $(X V A L)$. Panel A reports estimates using a sample of M\&A deals in which the percentage sought is above $50 \%$. Panel B reports estimates using the Fama-French 38 industry classification to calculate XVAL. Panel C reports estimates using U.S. and non-U.S. firms and the 2-digit SIC industry classification. Column (6) reports instrumental variables estimates in which import penetration $(I M P)$ is used as an instrument for XVAL. Regressions include the same control variables as in Table 4 (coefficients not shown) and year fixed effects. All explanatory variables are lagged one year. The sample consists of Worldscope firms for which GOV41 data are available in the 2004-2008 period. Variable definitions are provided in Table B1 in the Appendix. Robust $p$-values adjusted for country-level clustering are reported in brackets. $*, * *, * *$ indicate significance at the $10 \%, 5 \%$ and $1 \%$ levels, respectively.

\begin{tabular}{|c|c|c|c|c|c|}
\hline \multicolumn{6}{|c|}{ Panel A: Majority stakes } \\
\hline & (1) & (2) & (3) & (4) & (5) \\
\hline$X V A L$ & $\begin{array}{c}0.0053 * * \\
(0.032)\end{array}$ & $\begin{array}{c}0.0027 * \\
(0.096)\end{array}$ & $\begin{array}{c}0.0163 * * \\
(0.041)\end{array}$ & $\begin{array}{c}0.0135 * * \\
(0.025)\end{array}$ & $\begin{array}{c}0.1009 * * \\
(0.044)\end{array}$ \\
\hline$I P$ & & $\begin{array}{l}0.0031 \\
(0.274)\end{array}$ & & $\begin{array}{l}0.0028 \\
(0.375)\end{array}$ & \\
\hline$X V A L \times I P$ & & $\begin{array}{c}0.0116^{* * *} \\
(0.013)\end{array}$ & & $\begin{array}{c}0.0695^{* *} \\
(0.011)\end{array}$ & \\
\hline$H H I$ & & & $\begin{array}{c}-0.0068 \\
(0.803)\end{array}$ & $\begin{array}{r}-0.0054 \\
(0.838)\end{array}$ & \\
\hline$X V A L \times H H I$ & & & $\begin{array}{c}-0.0236^{*} \\
(0.060)\end{array}$ & $\begin{array}{c}-0.0245^{*} \\
(0.057)\end{array}$ & \\
\hline$H H I \times I P$ & & & & $\begin{array}{c}-0.0032 \\
(0.730)\end{array}$ & \\
\hline$X V A L \times H H I \times I P$ & & & & $\begin{array}{c}-0.0958 * * \\
(0.033)\end{array}$ & \\
\hline Number of observations & 7,398 & 7,398 & 7,384 & 7,384 & 7,313 \\
\hline R-squared & 0.876 & 0.876 & 0.876 & 0.876 & - \\
\hline \multicolumn{6}{|c|}{ Panel B: 38 Fama-French industries } \\
\hline & $(1)$ & $(2)$ & (3) & (4) & (5) \\
\hline$X V A L$ & $\begin{array}{c}0.0135^{* * * *} \\
(0.002)\end{array}$ & $\begin{array}{c}0.0089^{*} \\
(0.065)\end{array}$ & $\begin{array}{c}0.0763 * * * \\
(0.002)\end{array}$ & $\begin{array}{c}0.0602 * * * \\
(0.003)\end{array}$ & $\begin{array}{c}0.1011 * * \\
(0.046)\end{array}$ \\
\hline$I P$ & & $\begin{array}{l}0.0035 \\
(0.278)\end{array}$ & & $\begin{array}{l}0.0011 \\
(0.719)\end{array}$ & \\
\hline$X V A L \times I P$ & & $\begin{array}{c}0.0073 \\
(0.251)\end{array}$ & & $\begin{array}{l}0.0529 \\
(0.204)\end{array}$ & \\
\hline$H H I$ & & & $\begin{array}{l}0.0149 \\
(0.538)\end{array}$ & $\begin{array}{l}0.0142 \\
(0.540)\end{array}$ & \\
\hline$X V A L \times H H I$ & & & $\begin{array}{c}-0.1086^{* * * *} \\
(0.009)\end{array}$ & $\begin{array}{c}-0.0883 * * \\
(0.017)\end{array}$ & \\
\hline$H H I \times I P$ & & & & $\begin{array}{l}0.0064 \\
(0.454)\end{array}$ & \\
\hline$X V A L \times H H I \times I P$ & & & & $\begin{array}{c}-0.0804 \\
(0.231)\end{array}$ & \\
\hline Number of observations & 7,397 & 7,397 & 7,368 & 7,368 & 7,293 \\
\hline R-squared & 0.875 & 0.876 & 0.876 & 0.876 & - \\
\hline
\end{tabular}


Panel C: Sample Including U.S. firms

\begin{tabular}{|c|c|c|c|c|c|}
\hline & $(1)$ & $(2)$ & (3) & (4) & $(5)$ \\
\hline$X V A L$ & $\begin{array}{c}0.0073 * * * \\
(0.001)\end{array}$ & $\begin{array}{c}0.0042 * * \\
(0.029)\end{array}$ & $\begin{array}{c}0.0146 * * * \\
(0.008)\end{array}$ & $\begin{array}{c}0.0112 * * \\
(0.035)\end{array}$ & $\begin{array}{c}0.1625^{* *} \\
(0.010)\end{array}$ \\
\hline$I P$ & & $\begin{array}{l}0.0021 \\
(0.259)\end{array}$ & & $\begin{array}{l}0.0020 \\
(0.224)\end{array}$ & \\
\hline$X V A L \times I P$ & & $\begin{array}{c}0.0138 * * * \\
(0.000)\end{array}$ & & $\begin{array}{l}0.0533 \\
(0.161)\end{array}$ & \\
\hline$H H I$ & & & $\begin{array}{c}-0.0068 \\
(0.709)\end{array}$ & $\begin{array}{c}-0.0048 \\
(0.798)\end{array}$ & \\
\hline$X V A L \times H H I$ & & & $\begin{array}{c}-0.0154 \\
(0.189)\end{array}$ & $\begin{array}{c}-0.0155 \\
(0.256)\end{array}$ & \\
\hline$H H I \times I P$ & & & & $\begin{array}{l}-0.0037 \\
(0.516)\end{array}$ & \\
\hline$X V A L \times H H I \times I P$ & & & & $\begin{array}{c}-0.0688 \\
(0.255)\end{array}$ & \\
\hline Number of observations & 24,749 & 24,749 & 24,712 & 24,712 & 24,346 \\
\hline R-squared & 0.920 & 0.921 & 0.921 & 0.921 & - \\
\hline
\end{tabular}




\section{Table 7 - Cross-Border M\&A and Non-Target Corporate Governance Subcategories}

This table presents estimates of firm fixed effects panel regressions of the corporate governance index (GOV4I) subcategories of non-target firms on the value of cross-border M\&A in a firm's country-industry as a fraction of market capitalization $(X V A L)$. Panel A presents the results for board attributes, Panel B for audit attributes, Panel C for anti-takeover provisions and Panel D for compensation and ownership attributes. Regressions include the same control variables as in Table 4 (coefficients not shown) and year fixed effects. All explanatory variables are lagged one year. The sample consists of Worldscope firms for which GOV41 data are available in the 2004-2008 period. Variable definitions are provided in Table B1 in the Appendix. Robust $p$-values adjusted for country-level clustering are reported in brackets. *, **, *** indicate significance at the $10 \%, 5 \%$ and $1 \%$ levels, respectively.

\begin{tabular}{|c|c|c|c|c|}
\hline \multicolumn{5}{|c|}{ Panel A: Board } \\
\hline & (1) & (2) & (3) & (4) \\
\hline XVAL & $\begin{array}{l}0.0033 \\
(0.185)\end{array}$ & $\begin{array}{l}-0.0001 \\
(0.962)\end{array}$ & $\begin{array}{l}0.0217 \\
(0.168)\end{array}$ & $\begin{array}{c}0.0223 * * \\
(0.023)\end{array}$ \\
\hline$I P$ & & $\begin{array}{l}0.0026 \\
(0.365)\end{array}$ & & $\begin{array}{l}0.0036 \\
(0.363)\end{array}$ \\
\hline$X V A L \times I P$ & & $\begin{array}{c}0.0155^{* *} \\
(0.028)\end{array}$ & & $\begin{array}{c}0.0711 * * * \\
(0.009)\end{array}$ \\
\hline$H H I$ & & & $\begin{array}{l}-0.0229 \\
(0.308)\end{array}$ & $\begin{array}{l}-0.0197 \\
(0.373)\end{array}$ \\
\hline$X V A L \times H H I$ & & & $\begin{array}{l}-0.0391 \\
(0.199)\end{array}$ & $\begin{array}{c}-0.0517 * * * \\
(0.009)\end{array}$ \\
\hline$H H I \times I P$ & & & & $\begin{array}{l}-0.0088 \\
(0.458)\end{array}$ \\
\hline$X V A L \times H H I \times I P$ & & & & $\begin{array}{c}-0.0827^{*} \\
(0.054)\end{array}$ \\
\hline Number of observations & 7,398 & 7,398 & 7,384 & 7,384 \\
\hline R-squared & 0.892 & 0.892 & 0.892 & 0.893 \\
\hline \multicolumn{5}{|c|}{ Panel B: Audit } \\
\hline & (1) & (2) & (3) & (4) \\
\hline XVAL & $\begin{array}{l}0.0036 \\
(0.678)\end{array}$ & $\begin{array}{l}0.0104 \\
(0.307)\end{array}$ & $\begin{array}{l}-0.0071 \\
(0.877)\end{array}$ & $\begin{array}{l}-0.0308 \\
(0.355)\end{array}$ \\
\hline$I P$ & & $\begin{array}{l}-0.0161 \\
(0.158)\end{array}$ & & $\begin{array}{c}-0.0297 * * \\
(0.033)\end{array}$ \\
\hline$X V A L \times I P$ & & $\begin{array}{l}-0.0287 \\
(0.170)\end{array}$ & & $\begin{array}{l}0.0422 \\
(0.740)\end{array}$ \\
\hline$H H I$ & & & $\begin{array}{l}0.0973 \\
(0.507)\end{array}$ & $\begin{array}{l}0.0801 \\
(0.582)\end{array}$ \\
\hline$X V A L \times H H I$ & & & $\begin{array}{l}0.0211 \\
(0.843)\end{array}$ & $\begin{array}{l}0.0982 \\
(0.247)\end{array}$ \\
\hline$H H I \times I P$ & & & & $\begin{array}{c}0.0548 * * \\
(0.032)\end{array}$ \\
\hline$X V A L \times H H I \times I P$ & & & & $\begin{array}{l}-0.1671 \\
(0.425)\end{array}$ \\
\hline Number of observations & 7,398 & 7,398 & 7,384 & 7,384 \\
\hline $\mathrm{R}$-squared & 0.681 & 0.681 & 0.681 & 0.682 \\
\hline
\end{tabular}


Panel C: Anti-takeover provisions

\begin{tabular}{|c|c|c|c|c|}
\hline & $(1)$ & $(2)$ & (3) & $(4)$ \\
\hline \multirow[t]{2}{*}{$X V A L$} & -0.0014 & -0.0007 & -0.0085 & -0.0066 \\
\hline & $(0.574)$ & $(0.665)$ & $(0.480)$ & $(0.525)$ \\
\hline \multirow[t]{2}{*}{$I P$} & & 0.0071 & & 0.0060 \\
\hline & & $(0.226)$ & & $(0.367)$ \\
\hline \multirow[t]{2}{*}{$X V A L \times I P$} & & -0.0043 & & -0.0394 \\
\hline & & $(0.341)$ & & $(0.169)$ \\
\hline \multirow[t]{2}{*}{$H H I$} & & & -0.0072 & -0.0133 \\
\hline & & & $(0.507)$ & $(0.264)$ \\
\hline \multirow{2}{*}{$X V A L \times H H I$} & & & 0.0156 & 0.0135 \\
\hline & & & $(0.464)$ & $(0.511)$ \\
\hline \multirow[t]{2}{*}{$H H I \times I P$} & & & & 0.0078 \\
\hline & & & & $(0.318)$ \\
\hline \multirow[t]{2}{*}{$X V A L \times H H I \times I P$} & & & & 0.0593 \\
\hline & & & & $(0.168)$ \\
\hline Number of observations & 7,398 & 7,398 & 7,384 & 7,384 \\
\hline \multirow[t]{3}{*}{ R-squared } & 0.785 & 0.785 & 0.785 & 0.786 \\
\hline & Panel D: C & sation and & nip & \\
\hline & $(1)$ & $(2)$ & (3) & (4) \\
\hline \multirow[t]{2}{*}{$X V A L$} & $0.0170 * *$ & $0.0103 *$ & $0.0287 * *$ & 0.0200 \\
\hline & $(0.034)$ & $(0.076)$ & $(0.026)$ & $(0.158)$ \\
\hline \multirow[t]{2}{*}{$I P$} & & 0.0031 & & 0.0027 \\
\hline & & $(0.528)$ & & $(0.460)$ \\
\hline \multirow[t]{2}{*}{$X V A L \times I P$} & & $0.0305 * *$ & & $0.1720 * * *$ \\
\hline & & $(0.016)$ & & $(0.009)$ \\
\hline \multirow[t]{2}{*}{$H H I$} & & & 0.0060 & 0.0110 \\
\hline & & & $(0.895)$ & $(0.813)$ \\
\hline \multirow[t]{2}{*}{$X V A L \times H H I$} & & & -0.0254 & -0.0212 \\
\hline & & & $(0.332)$ & $(0.582)$ \\
\hline \multirow[t]{2}{*}{$H H I \times I P$} & & & & -0.0086 \\
\hline & & & & $(0.707)$ \\
\hline \multirow[t]{2}{*}{$X V A L \times H H I \times I P$} & & & & $-0.2468 * *$ \\
\hline & & & & $(0.025)$ \\
\hline Number of observations & 7,398 & 7,398 & 7,384 & 7,384 \\
\hline R-squared & 0.736 & 0.736 & 0.736 & 0.737 \\
\hline
\end{tabular}




\section{Table 8 - Cross-Border M\&A and Non-Target Firm Valuation: Firm Fixed Effects}

This table presents estimates of firm fixed effects panel regressions of the market-to-book ratio $(M B)$ of non-target firms on the value of cross-border M\&A in a firm's country-industry as a fraction of market capitalization (XVAL). Regressions include year fixed effects and are estimated by GMM using the Arellano-Bover/Blundell-Bond estimator with forward orthogonal deviations. All explanatory variables are lagged one year. The sample consists of Worldscope firms for which GOV41 data are available in the 2004-2008 period. Variable definitions are provided in Table B1 in the Appendix. Robust $p$-values adjusted for country-level clustering are reported in brackets. *, **,*** indicate significance at the $10 \%, 5 \%$ and $1 \%$ levels, respectively.

\begin{tabular}{|c|c|c|c|c|c|}
\hline & $(1)$ & (2) & (3) & (4) & $(5)$ \\
\hline$X V A L$ & & $\begin{array}{c}0.3951 * * * \\
(0.000)\end{array}$ & $\begin{array}{c}0.4895 * * * \\
(0.000)\end{array}$ & $\begin{array}{c}0.9955 * * * \\
(0.000)\end{array}$ & $\begin{array}{c}0.8633 * * * \\
(0.005)\end{array}$ \\
\hline$I P$ & & & $\begin{array}{l}0.0184 \\
(0.668)\end{array}$ & & $\begin{array}{l}0.0115 \\
(0.825)\end{array}$ \\
\hline$X V A L \times I P$ & & & $\begin{array}{c}-0.5557 * * * \\
(0.002)\end{array}$ & & $\begin{array}{c}-0.0982 \\
(0.896)\end{array}$ \\
\hline$H H I$ & & & & $\begin{array}{c}0.3003 * * \\
(0.027)\end{array}$ & $\begin{array}{c}0.3033^{*} \\
(0.095)\end{array}$ \\
\hline$X V A L \times H H I$ & & & & $\begin{array}{c}-1.3503 * * * \\
(0.000)\end{array}$ & $\begin{array}{c}-0.8808 \\
(0.299)\end{array}$ \\
\hline$H H I \times I P$ & & & & & $\begin{array}{r}-0.0069 \\
(0.964)\end{array}$ \\
\hline$X V A L \times H H I \times I P$ & & & & & $\begin{array}{r}-0.6694 \\
(0.613)\end{array}$ \\
\hline SIZE & $\begin{array}{c}-0.0720 * * \\
(0.030)\end{array}$ & $\begin{array}{c}-0.0560 * * \\
(0.020)\end{array}$ & $\begin{array}{c}-0.0567 * * \\
(0.019)\end{array}$ & $\begin{array}{c}-0.0530 * * \\
(0.028)\end{array}$ & $\begin{array}{c}-0.0538 * * \\
(0.026)\end{array}$ \\
\hline SGROWTH & $\begin{array}{r}-0.1445 \\
(0.110)\end{array}$ & $\begin{array}{c}-0.1467 * \\
(0.087)\end{array}$ & $\begin{array}{c}-0.1471 * \\
(0.087)\end{array}$ & $\begin{array}{c}-0.1535^{*} \\
(0.070)\end{array}$ & $\begin{array}{c}-0.1547 * \\
(0.069)\end{array}$ \\
\hline LEVERAGE & $\begin{array}{c}0.7959 * * * \\
(0.002)\end{array}$ & $\begin{array}{c}0.6905 * * * \\
(0.002)\end{array}$ & $\begin{array}{c}0.6929 * * * \\
(0.002)\end{array}$ & $\begin{array}{c}0.6547 * * * \\
(0.003)\end{array}$ & $\begin{array}{c}0.6583 * * * \\
(0.003)\end{array}$ \\
\hline CASH & $\begin{array}{c}0.9899 * * \\
(0.010)\end{array}$ & $\begin{array}{c}0.9074 * * * \\
(0.009)\end{array}$ & $\begin{array}{c}0.9079 * * * \\
(0.008)\end{array}$ & $\begin{array}{c}0.9164 * * * \\
(0.008)\end{array}$ & $\begin{array}{c}0.9154 * * * \\
(0.008)\end{array}$ \\
\hline CAPEX & $\begin{array}{c}1.4634 * \\
(0.052)\end{array}$ & $\begin{array}{c}1.2724 * * \\
(0.040)\end{array}$ & $\begin{array}{c}1.2807 * * \\
(0.040)\end{array}$ & $\begin{array}{c}1.1865 * \\
(0.062)\end{array}$ & $\begin{array}{l}1.1873 * \\
(0.061)\end{array}$ \\
\hline$M B$ & $\begin{array}{c}0.5146 * * * \\
(0.000)\end{array}$ & $\begin{array}{c}0.5719 * * * \\
(0.000)\end{array}$ & $\begin{array}{c}0.5711 * * * \\
(0.000)\end{array}$ & $\begin{array}{c}0.5784 * * * \\
(0.000)\end{array}$ & $\begin{array}{c}0.5779 * * * \\
(0.000)\end{array}$ \\
\hline$R O A$ & $\begin{array}{l}1.3244^{*} \\
(0.069)\end{array}$ & $\begin{array}{l}1.1190 * \\
(0.062)\end{array}$ & $\begin{array}{l}1.1274 * \\
(0.062)\end{array}$ & $\begin{array}{c}1.0735^{*} \\
(0.076)\end{array}$ & $\begin{array}{l}1.0794 * \\
(0.076)\end{array}$ \\
\hline$R \& D$ & $\begin{array}{c}2.0026 * * \\
(0.011)\end{array}$ & $\begin{array}{c}1.7529 * * * \\
(0.009)\end{array}$ & $\begin{array}{c}1.7549 * * * \\
(0.009)\end{array}$ & $\begin{array}{c}1.8037 * * * \\
(0.004)\end{array}$ & $\begin{array}{c}1.8109 * * * \\
(0.004)\end{array}$ \\
\hline$P P E$ & $\begin{array}{c}-0.3037 \\
(0.129)\end{array}$ & $\begin{array}{c}-0.2534 \\
(0.124)\end{array}$ & $\begin{array}{c}-0.2568 \\
(0.127)\end{array}$ & $\begin{array}{c}-0.2564 \\
(0.136)\end{array}$ & $\begin{array}{c}-0.2566 \\
(0.132)\end{array}$ \\
\hline FXSALES & $\begin{array}{c}-0.0983 \\
(0.200)\end{array}$ & $\begin{array}{r}-0.1049 \\
(0.125)\end{array}$ & $\begin{array}{r}-0.1017 \\
(0.138)\end{array}$ & $\begin{array}{c}-0.1179 * \\
(0.080)\end{array}$ & $\begin{array}{c}-0.1167 * \\
(0.085)\end{array}$ \\
\hline ANALYST & $\begin{array}{c}0.0209 * * * \\
(0.000)\end{array}$ & $\begin{array}{c}0.0162 * * * \\
(0.001)\end{array}$ & $\begin{array}{c}0.0164 * * * \\
(0.001)\end{array}$ & $\begin{array}{c}0.0142 * * * \\
(0.001)\end{array}$ & $\begin{array}{c}0.0143 * * * \\
(0.002)\end{array}$ \\
\hline CLOSE & $\begin{array}{c}-0.1172 \\
(0.568)\end{array}$ & $\begin{array}{c}-0.0963 \\
(0.586)\end{array}$ & $\begin{array}{c}-0.0990 \\
(0.575)\end{array}$ & $\begin{array}{c}-0.1053 \\
(0.545)\end{array}$ & $\begin{array}{r}-0.1089 \\
(0.534)\end{array}$ \\
\hline$A D R$ & $\begin{array}{c}0.0963 \\
(0.311)\end{array}$ & $\begin{array}{c}0.0861 \\
(0.296)\end{array}$ & $\begin{array}{l}0.0844 \\
(0.307)\end{array}$ & $\begin{array}{l}0.0846 \\
(0.313)\end{array}$ & $\begin{array}{l}0.0836 \\
(0.320)\end{array}$ \\
\hline IO_TOTAL & $\begin{array}{c}-0.0013 \\
(0.992)\end{array}$ & $\begin{array}{c}-0.0085 \\
(0.942)\end{array}$ & $\begin{array}{r}-0.0101 \\
(0.932)\end{array}$ & $\begin{array}{r}-0.0131 \\
(0.908)\end{array}$ & $\begin{array}{c}-0.0110 \\
(0.921)\end{array}$ \\
\hline$D M A$ & & $\begin{array}{c}-0.1140 * \\
(0.095)\end{array}$ & $\begin{array}{r}-0.1046 \\
(0.165)\end{array}$ & $\begin{array}{l}-0.0604 \\
(0.306)\end{array}$ & $\begin{array}{l}-0.0545 \\
(0.454)\end{array}$ \\
\hline Number of observations & 6,843 & 6,863 & 6,863 & 6,849 & 6,849 \\
\hline
\end{tabular}




\section{Table 9 - Cross-Border M\&A and Non-Target Firm Valuation: First Differences}

This table presents estimates of first differences panel regressions of the market-to-book ratio $(M B)$ of non-target firms on the value of cross-border M\&A in a firm's country-industry as a fraction of market capitalization (XVAL). Regressions include country, industry and year fixed effects. All explanatory variables are lagged one year. The sample consists of Worldscope firms for which GOV41 data are available in the 2004-2008 period. Variable definitions are provided in Table B1 in the Appendix. Robust $p$-values adjusted for country-level clustering are reported in brackets. $* * *, * * *$ indicate significance at the $10 \%, 5 \%$ and $1 \%$ levels, respectively.

\begin{tabular}{|c|c|c|c|c|c|}
\hline & (1) & (2) & (3) & (4) & (5) \\
\hline$\triangle X V A L$ & & $\begin{array}{c}0.3851 \text { *** } \\
(0.003)\end{array}$ & $\begin{array}{c}0.4726 \text { *** } \\
(0.001)\end{array}$ & $\begin{array}{c}0.8951 * * * \\
(0.000)\end{array}$ & $\begin{array}{c}0.8754 * * * \\
(0.000)\end{array}$ \\
\hline$\Delta I P$ & & & $\begin{array}{l}0.0337 \\
(0.404)\end{array}$ & & $\begin{array}{l}0.0258 \\
(0.642)\end{array}$ \\
\hline$\Delta(X V A L \times I P)$ & & & $\begin{array}{c}-0.5946 * * * \\
(0.002)\end{array}$ & & $\begin{array}{c}-1.0830 \\
(0.232)\end{array}$ \\
\hline$\Delta H H I$ & & & & $\begin{array}{c}-0.9062 * * \\
(0.025)\end{array}$ & $\begin{array}{c}-0.9260 * * \\
(0.020)\end{array}$ \\
\hline$\Delta(X V A L \times H H I)$ & & & & $\begin{array}{c}-1.1295 * * * \\
(0.001)\end{array}$ & $\begin{array}{c}-0.9508^{*} \\
(0.051)\end{array}$ \\
\hline$\Delta(H H I \times I P)$ & & & & & $\begin{array}{l}0.0480 \\
(0.813)\end{array}$ \\
\hline$\Delta(X V A L \times H H I \times I P)$ & & & & & $\begin{array}{l}1.1812 \\
(0.412)\end{array}$ \\
\hline$\triangle S I Z E$ & $\begin{array}{c}-0.2205 \\
(0.337)\end{array}$ & $\begin{array}{l}-0.2252 \\
(0.331)\end{array}$ & $\begin{array}{c}-0.2262 \\
(0.328)\end{array}$ & $\begin{array}{c}-0.2194 \\
(0.349)\end{array}$ & $\begin{array}{r}-0.2212 \\
(0.343)\end{array}$ \\
\hline$\triangle S G R O W T H$ & $\begin{array}{c}-0.2279 * * \\
(0.045)\end{array}$ & $\begin{array}{c}-0.2267 * * \\
(0.044)\end{array}$ & $\begin{array}{c}-0.2276^{* *} \\
(0.044)\end{array}$ & $\begin{array}{c}-0.2204 * * \\
(0.048)\end{array}$ & $\begin{array}{c}-0.2218 * * \\
(0.048)\end{array}$ \\
\hline$\triangle L E V E R A G E$ & $\begin{array}{l}-0.3050 \\
(0.512)\end{array}$ & $\begin{array}{c}-0.3928 \\
(0.440)\end{array}$ & $\begin{array}{c}-0.4052 \\
(0.438)\end{array}$ & $\begin{array}{r}-0.4203 \\
(0.414)\end{array}$ & $\begin{array}{c}-0.4279 \\
(0.409)\end{array}$ \\
\hline$\triangle C A S H$ & $\begin{array}{c}1.0643 * * \\
(0.048)\end{array}$ & $\begin{array}{c}1.0923 * * \\
(0.039)\end{array}$ & $\begin{array}{c}1.1025 * * \\
(0.039)\end{array}$ & $\begin{array}{c}1.0867 * * \\
(0.041)\end{array}$ & $\begin{array}{c}1.0919 * * \\
(0.041)\end{array}$ \\
\hline$\triangle C A P E X$ & $\begin{array}{l}0.2321 \\
(0.593)\end{array}$ & $\begin{array}{l}0.3020 \\
(0.476)\end{array}$ & $\begin{array}{l}0.3174 \\
(0.450)\end{array}$ & $\begin{array}{l}0.2876 \\
(0.502)\end{array}$ & $\begin{array}{c}0.2938 \\
(0.491)\end{array}$ \\
\hline$\Delta M B$ & $\begin{array}{c}-0.1423 * * * \\
(0.001)\end{array}$ & $\begin{array}{c}-0.1436 * * * \\
(0.001)\end{array}$ & $\begin{array}{c}-0.1440 * * * \\
(0.001)\end{array}$ & $\begin{array}{c}-0.1439 * * * \\
(0.001)\end{array}$ & $\begin{array}{c}-0.1444 * * * \\
(0.001)\end{array}$ \\
\hline$\triangle R O A$ & $\begin{array}{l}0.4724 \\
(0.165)\end{array}$ & $\begin{array}{l}0.4837 \\
(0.170)\end{array}$ & $\begin{array}{l}0.5006 \\
(0.165)\end{array}$ & $\begin{array}{l}0.4845 \\
(0.165)\end{array}$ & $\begin{array}{l}0.4941 \\
(0.162)\end{array}$ \\
\hline$\Delta R \& D$ & $\begin{array}{l}-1.1707 \\
(0.199)\end{array}$ & $\begin{array}{l}-0.7289 \\
(0.360)\end{array}$ & $\begin{array}{r}-0.7359 \\
(0.353)\end{array}$ & $\begin{array}{r}-0.7324 \\
(0.365)\end{array}$ & $\begin{array}{r}-0.7377 \\
(0.358)\end{array}$ \\
\hline$\triangle P P E$ & $\begin{array}{l}0.5027 \\
(0.468)\end{array}$ & $\begin{array}{c}0.4978 \\
(0.473)\end{array}$ & $\begin{array}{c}0.4956 \\
(0.476)\end{array}$ & $\begin{array}{l}0.5039 \\
(0.470)\end{array}$ & $\begin{array}{l}0.5071 \\
(0.468)\end{array}$ \\
\hline$\triangle F X S A L E S$ & $\begin{array}{c}-0.1233 \\
(0.477)\end{array}$ & $\begin{array}{l}-0.1115 \\
(0.534)\end{array}$ & $\begin{array}{l}-0.1093 \\
(0.529)\end{array}$ & $\begin{array}{r}-0.1075 \\
(0.552)\end{array}$ & $\begin{array}{c}-0.1025 \\
(0.562)\end{array}$ \\
\hline$\triangle A N A L Y S T$ & $\begin{array}{c}-0.0015 \\
(0.835)\end{array}$ & $\begin{array}{l}-0.0021 \\
(0.776)\end{array}$ & $\begin{array}{l}-0.0021 \\
(0.778)\end{array}$ & $\begin{array}{r}-0.0028 \\
(0.692)\end{array}$ & $\begin{array}{l}-0.0027 \\
(0.697)\end{array}$ \\
\hline$\triangle C L O S E$ & $\begin{array}{c}-0.2909 \\
(0.127)\end{array}$ & $\begin{array}{c}-0.3264 * \\
(0.075)\end{array}$ & $\begin{array}{c}-0.3279 * \\
(0.069)\end{array}$ & $\begin{array}{c}-0.3633^{*} \\
(0.051)\end{array}$ & $\begin{array}{c}-0.3662 * * \\
(0.048)\end{array}$ \\
\hline$\triangle A D R$ & $\begin{array}{l}0.2787 \\
(0.471)\end{array}$ & $\begin{array}{l}0.2767 \\
(0.469)\end{array}$ & $\begin{array}{c}0.2782 \\
(0.466)\end{array}$ & $\begin{array}{l}0.2887 \\
(0.456)\end{array}$ & $\begin{array}{c}0.2882 \\
(0.456)\end{array}$ \\
\hline$\triangle I O \_T O T A L$ & $\begin{array}{l}0.0600 \\
(0.447)\end{array}$ & $\begin{array}{l}0.0547 \\
(0.515)\end{array}$ & $\begin{array}{l}0.0504 \\
(0.560)\end{array}$ & $\begin{array}{l}0.0485 \\
(0.554)\end{array}$ & $\begin{array}{l}0.0495 \\
(0.557)\end{array}$ \\
\hline$\triangle D M A$ & & $\begin{array}{r}-0.0035 \\
(0.957)\end{array}$ & $\begin{array}{l}0.0096 \\
(0.883)\end{array}$ & $\begin{array}{c}-0.0042 \\
(0.947)\end{array}$ & $\begin{array}{l}0.0169 \\
(0.805)\end{array}$ \\
\hline $\begin{array}{l}\text { Number of observations } \\
\text { R-squared }\end{array}$ & $\begin{array}{l}5,378 \\
0.131\end{array}$ & $\begin{array}{l}5,354 \\
0.135\end{array}$ & $\begin{array}{l}5,354 \\
0.136\end{array}$ & $\begin{array}{l}5,343 \\
0.137\end{array}$ & $\begin{array}{l}5,343 \\
0.137\end{array}$ \\
\hline
\end{tabular}




\section{Table 10 - Cross-Border M\&A and Non-Target Firm Productivity: Firm Fixed Effects}

This table presents estimates of firm fixed effects panel regressions of the productivity of capital defined as the logarithm of the ratio of sales to capital $(P R O D K)$ of non-target firms on the value of cross-border M\&A in a firm's country-industry as a fraction of market capitalization (XVAL). Regressions include year fixed effects. All explanatory variables are lagged one year. The sample consists of Worldscope firms for which GOV41 data are available in the 2004-2008 period. Variable definitions are provided in Table B1 in the Appendix. Robust $p$-values adjusted for country-level clustering are reported in brackets. $*$, **, *** indicate significance at the $10 \%, 5 \%$ and $1 \%$ levels, respectively.

\begin{tabular}{|c|c|c|c|c|c|}
\hline & $(1)$ & $(2)$ & (3) & (4) & $(5)$ \\
\hline \multirow[t]{2}{*}{$X V A L$} & & 0.0010 & 0.0029 & $0.1171 * * *$ & $0.1100 * * *$ \\
\hline & & $(0.922)$ & $(0.834)$ & $(0.001)$ & $(0.006)$ \\
\hline \multirow[t]{2}{*}{$I P$} & & & 0.0069 & & 0.0187 \\
\hline & & & $(0.301)$ & & $(0.143)$ \\
\hline \multirow{2}{*}{$X V A L \times I P$} & & & -0.0125 & & 0.0775 \\
\hline & & & $(0.806)$ & & $(0.562)$ \\
\hline \multirow[t]{2}{*}{$H H I$} & & & & 0.1034 & 0.1358 \\
\hline & & & & $(0.425)$ & $(0.286)$ \\
\hline \multirow[t]{2}{*}{$X V A L \times H H I$} & & & & $-0.2567 * * *$ & $-0.2474 * * *$ \\
\hline & & & & $(0.001)$ & $(0.002)$ \\
\hline \multirow[t]{2}{*}{$I P \times H H I$} & & & & & $-0.0647 *$ \\
\hline & & & & & $(0.079)$ \\
\hline \multirow[t]{2}{*}{$X V A L \times I P \times H H I$} & & & & & -0.1123 \\
\hline & & & & & $(0.570)$ \\
\hline \multirow[t]{2}{*}{ SIZE } & -0.0349 & -0.0349 & -0.0349 & -0.0339 & -0.0337 \\
\hline & $(0.158)$ & $(0.158)$ & $(0.159)$ & $(0.172)$ & $(0.175)$ \\
\hline \multirow[t]{2}{*}{ SGROWTH } & $0.1565^{* *}$ & $0.1565^{* *}$ & $0.1566^{* *}$ & $0.1559 * *$ & $0.1562 * *$ \\
\hline & $(0.020)$ & $(0.021)$ & $(0.021)$ & $(0.021)$ & $(0.021)$ \\
\hline \multirow[t]{2}{*}{ LEVERAGE } & -0.0521 & -0.0521 & -0.0524 & -0.0532 & -0.0519 \\
\hline & $(0.372)$ & $(0.376)$ & $(0.375)$ & $(0.373)$ & $(0.380)$ \\
\hline \multirow[t]{2}{*}{$\mathrm{CASH}$} & $0.1389 *$ & $0.1389 *$ & $0.1403 *$ & $0.1428 *$ & $0.1453 *$ \\
\hline & $(0.072)$ & $(0.072)$ & $(0.069)$ & $(0.066)$ & $(0.063)$ \\
\hline \multirow[t]{2}{*}{ CAPEX } & -0.7618 & -0.7618 & -0.7598 & -0.7530 & -0.7459 \\
\hline & $(0.157)$ & $(0.157)$ & $(0.160)$ & $(0.158)$ & $(0.162)$ \\
\hline \multirow[t]{2}{*}{$M B$} & 0.0008 & 0.0008 & 0.0008 & 0.0008 & 0.0009 \\
\hline & $(0.625)$ & $(0.625)$ & $(0.636)$ & $(0.649)$ & $(0.624)$ \\
\hline \multirow[t]{2}{*}{$R O A$} & -0.1329 & -0.1329 & -0.1326 & -0.1331 & -0.1332 \\
\hline & $(0.253)$ & $(0.253)$ & $(0.253)$ & $(0.249)$ & $(0.246)$ \\
\hline \multirow[t]{2}{*}{$R \& D$} & 0.3706 & 0.3705 & 0.3685 & 0.3801 & 0.3854 \\
\hline & $(0.512)$ & $(0.512)$ & $(0.518)$ & $(0.502)$ & $(0.498)$ \\
\hline \multirow[t]{2}{*}{ FXSALES } & $0.0844 *$ & $0.0844 *$ & $0.0845^{*}$ & $0.0829 *$ & $0.0817 *$ \\
\hline & $(0.065)$ & $(0.065)$ & $(0.066)$ & $(0.067)$ & $(0.069)$ \\
\hline \multirow[t]{2}{*}{ ANALYST } & 0.0006 & 0.0006 & 0.0005 & 0.0005 & 0.0004 \\
\hline & $(0.822)$ & $(0.823)$ & $(0.842)$ & $(0.841)$ & $(0.868)$ \\
\hline \multirow[t]{2}{*}{ CLOSE } & 0.0159 & 0.0158 & 0.0150 & 0.0151 & 0.0140 \\
\hline & $(0.848)$ & $(0.849)$ & $(0.858)$ & $(0.856)$ & $(0.867)$ \\
\hline \multirow[t]{2}{*}{$A D R$} & -0.0179 & -0.0179 & -0.0187 & -0.0192 & -0.0177 \\
\hline & $(0.841)$ & $(0.841)$ & $(0.833)$ & $(0.830)$ & $(0.843)$ \\
\hline \multirow[t]{2}{*}{ IO_TOTAL } & -0.0147 & -0.0148 & -0.0154 & -0.0178 & -0.0188 \\
\hline & $(0.592)$ & $(0.591)$ & $(0.572)$ & $(0.512)$ & $(0.475)$ \\
\hline \multirow[t]{2}{*}{ EMPLOYEES } & -0.0437 & -0.0437 & -0.0437 & -0.0421 & -0.0421 \\
\hline & $(0.257)$ & $(0.256)$ & $(0.258)$ & $(0.274)$ & $(0.278)$ \\
\hline \multirow[t]{2}{*}{$D M A$} & & 0.0007 & 0.0040 & -0.0000 & -0.0044 \\
\hline & & $(0.967)$ & $(0.814)$ & $(0.998)$ & $(0.803)$ \\
\hline Number of observations & 6,949 & 6,949 & 6,949 & 6,935 & 6,935 \\
\hline R-squared & 0.962 & 0.962 & 0.962 & 0.962 & 0.962 \\
\hline
\end{tabular}




\section{Table 11 - Cross-Border M\&A and Non-Target Firm Productivity: First Differences}

This table presents estimates of first differences panel regressions of the productivity of capital defined as the logarithm of the ratio of sales to capital $(P R O D K)$ of non-target firms on the value of cross-border M\&A in a firm's country-industry as a fraction of market capitalization $(X V A L)$. Regressions include country, industry and year fixed effects. All explanatory variables are lagged one year. The sample consists of Worldscope firms for which GOV4I data are available in the 2004-2008 period. Variable definitions are provided in Table B1 in the Appendix. Robust $p$ values adjusted for country-level clustering are reported in brackets. *, **, *** indicate significance at the 10\%, 5\% and $1 \%$ levels, respectively.

\begin{tabular}{|c|c|c|c|c|c|}
\hline & $(1)$ & $(2)$ & (3) & $(4)$ & $(5)$ \\
\hline \multirow[t]{2}{*}{$\overline{\triangle X V A L}$} & & 0.0078 & 0.0111 & $0.0924 * *$ & $0.1044 * *$ \\
\hline & & $(0.432)$ & $(0.432)$ & $(0.014)$ & $(0.011)$ \\
\hline \multirow[t]{2}{*}{$\Delta I P$} & & & 0.0105 & & 0.0238 \\
\hline & & & $(0.261)$ & & $(0.113)$ \\
\hline \multirow[t]{2}{*}{$\Delta(X V A L \times I P)$} & & & -0.0222 & & -0.1187 \\
\hline & & & $(0.619)$ & & $(0.426)$ \\
\hline \multirow[t]{2}{*}{$\Delta H H I$} & & & & 0.0183 & 0.0391 \\
\hline & & & & $(0.847)$ & $(0.704)$ \\
\hline \multirow[t]{2}{*}{$\Delta(X V A L \times H H I)$} & & & & $-0.1893 * * *$ & $-0.2212 * * *$ \\
\hline & & & & (0.009) & $(0.005)$ \\
\hline \multirow[t]{2}{*}{$\Delta(H H I \times I P)$} & & & & & -0.0522 \\
\hline & & & & & $(0.102)$ \\
\hline \multirow[t]{2}{*}{$\Delta(X V A L \times H H I \times I P)$} & & & & & 0.2368 \\
\hline & & & & & $(0.285)$ \\
\hline \multirow[t]{2}{*}{$\triangle S I Z E$} & 0.0472 & 0.0469 & 0.0466 & 0.0474 & 0.0474 \\
\hline & $(0.167)$ & $(0.170)$ & $(0.176)$ & $(0.167)$ & $(0.170)$ \\
\hline \multirow[t]{2}{*}{$\triangle S G R O W T H$} & 0.0344 & 0.0344 & 0.0343 & 0.0343 & 0.0343 \\
\hline & $(0.333)$ & $(0.333)$ & $(0.334)$ & $(0.331)$ & $(0.333)$ \\
\hline \multirow[t]{2}{*}{$\triangle L E V E R A G E$} & 0.0610 & 0.0593 & 0.0592 & 0.0577 & 0.0602 \\
\hline & $(0.123)$ & $(0.144)$ & $(0.151)$ & $(0.160)$ & $(0.154)$ \\
\hline \multirow[t]{2}{*}{$\triangle C A S H$} & -0.0772 & -0.0775 & -0.0768 & -0.0760 & -0.0747 \\
\hline & $(0.151)$ & $(0.149)$ & $(0.149)$ & $(0.158)$ & $(0.167)$ \\
\hline \multirow[t]{2}{*}{$\triangle C A P E X$} & -0.3191 & -0.3190 & -0.3177 & -0.3147 & -0.3103 \\
\hline & $(0.247)$ & $(0.246)$ & $(0.248)$ & $(0.249)$ & $(0.253)$ \\
\hline \multirow[t]{2}{*}{$\Delta M B$} & $-0.0017 * *$ & $-0.0017 * *$ & $-0.0017 * *$ & $-0.0017 * *$ & $-0.0017 * *$ \\
\hline & $(0.016)$ & $(0.016)$ & $(0.018)$ & $(0.017)$ & $(0.020)$ \\
\hline \multirow[t]{2}{*}{$\triangle R O A$} & $-0.2465 * *$ & $-0.2456 * *$ & $-0.2433^{*}$ & $-0.2439 * *$ & $-0.2416^{*}$ \\
\hline & $(0.048)$ & $(0.049)$ & $(0.051)$ & (0.049) & $(0.050)$ \\
\hline \multirow[t]{2}{*}{$\Delta R \& D$} & $-0.7336^{*}$ & $-0.7334 *$ & $-0.7336^{*}$ & $-0.7308^{*}$ & $-0.7287^{*}$ \\
\hline & $(0.061)$ & $(0.061)$ & $(0.061)$ & $(0.063)$ & $(0.064)$ \\
\hline \multirow[t]{2}{*}{$\triangle F X S A L E S$} & 0.0395 & 0.0394 & 0.0395 & 0.0392 & 0.0385 \\
\hline & $(0.246)$ & $(0.246)$ & $(0.249)$ & $(0.248)$ & $(0.264)$ \\
\hline \multirow[t]{2}{*}{$\triangle A N A L Y S T$} & 0.0013 & 0.0013 & 0.0012 & 0.0012 & 0.0013 \\
\hline & $(0.480)$ & $(0.486)$ & $(0.492)$ & $(0.499)$ & $(0.477)$ \\
\hline \multirow{2}{*}{$\triangle C L O S E$} & 0.0505 & 0.0501 & 0.0498 & 0.0494 & 0.0471 \\
\hline & $(0.464)$ & $(0.469)$ & $(0.475)$ & $(0.474)$ & $(0.498)$ \\
\hline \multirow[t]{2}{*}{$\triangle A D R$} & -0.0967 & -0.0963 & -0.0976 & -0.0956 & -0.0956 \\
\hline & $(0.330)$ & $(0.330)$ & $(0.319)$ & $(0.333)$ & $(0.330)$ \\
\hline \multirow[t]{2}{*}{$\triangle I O \_T O T A L$} & 0.0160 & 0.0155 & 0.0150 & 0.0135 & 0.0127 \\
\hline & $(0.418)$ & $(0.428)$ & $(0.435)$ & $(0.457)$ & $(0.469)$ \\
\hline \multirow[t]{2}{*}{$\triangle E M P L O Y E E S$} & -0.0095 & -0.0093 & -0.0091 & -0.0084 & -0.0080 \\
\hline & $(0.828)$ & $(0.831)$ & $(0.835)$ & $(0.848)$ & $(0.856)$ \\
\hline \multirow[t]{2}{*}{$\triangle D M A$} & & 0.0062 & 0.0096 & 0.0077 & 0.0083 \\
\hline & & $(0.811)$ & $(0.705)$ & $(0.763)$ & $(0.741)$ \\
\hline Observations & 5,071 & 5,071 & 5,071 & 5,060 & 5,060 \\
\hline R-squared & 0.038 & 0.038 & 0.038 & 0.039 & 0.039 \\
\hline
\end{tabular}

